\title{
A First Look at Dissolved Ge Isotopes in Marine Sediments
}

\author{
J. Jotautas Baronas ${ }^{1 * t}$, Douglas E. Hammond ${ }^{1}$, Olivier J. Rouxel ${ }^{2}$ and \\ Danielle R. Monteverde ${ }^{1 \dagger}$
}

${ }^{1}$ Department of Earth Sciences, University of Southern California, Los Angeles, CA, United States, ${ }^{2}$ IFREMER, Centre de Brest, Unité Géosciences Marines, Plouzané, France

\section{OPEN ACCESS}

Edited by:

Gilad Antler,

Ben-Gurion University of the Negev,

Israe

Reviewed by:

Claudia Ehlert,

University of Oldenburg, Germany

Albert Galy,

Université de Lorraine, France

*Correspondence:

J. Jotautas Baronas

jotautas.baronas@gmail.com

${ }^{\dagger}$ Present Address:

J. Jotautas Baronas,

Department of Earth Sciences,

University of Cambridge, Cambridge,

United Kingdom

Danielle R. Monteverde

Division of Geology and Planetary

Sciences, California Institute of Technology, Pasadena, CA, United States

Specialty section:

This article was submitted to Biogeoscience,

a section of the journal

Frontiers in Earth Science

Received: 14 April 2019

Accepted: 06 June 2019

Published: 21 June 2019

Citation:

Baronas JJ, Hammond DE, Rouxel OJ and Monteverde DR (2019) A First Look at Dissolved Ge Isotopes in Marine Sediments.

Front. Earth Sci. 7:162. doi: 10.3389/feart.2019.00162
The removal of chemical species from seawater during the precipitation of authigenic minerals is difficult to constrain but may play a major role in the global biogeochemical cycles of some elements, including silicon (Si) and germanium (Ge). Here, we present $\mathrm{Ge} / \mathrm{Si}, \delta^{74} \mathrm{Ge}$, and supporting chemical data of pore waters and core incubations at three continental margin sites in California and the Gulf of Mexico. We used these data to partition Ge release and uptake by the various allogenic (delivered via sedimentation) and authigenic (formed in situ) phases in these sediments. About half of the pore water $\mathrm{Ge}\left(\delta^{74} \mathrm{Ge}_{\mathrm{pw}}=1.3-2.4 \%\right)$ is supplied by biogenic silica dissolution $\left(\delta^{74} \mathrm{Ge} \sim 3 \%\right)$, with the other half contributed by lithogenic particulates $\left(\delta^{74} \mathrm{Ge} \sim 0.6 \%\right)$. The highest $\mathrm{Ge} / \mathrm{Si}(\sim 3 \mu \mathrm{mol} / \mathrm{mol})$ and lowest $\delta^{74} \mathrm{Ge}(1.3-1.9 \%)$ are observed at the Fe redox horizon, suggesting a supply from detrital Ge-rich Fe oxides. The precipitation of authigenic phases (most likely aluminosilicate clays) in deeper sediments preferentially incorporates Ge over Si, resulting in low pore water $\mathrm{Ge} / \mathrm{Si}(\sim 0.3 \mu \mathrm{mol} / \mathrm{mol})$. The lack of corresponding $\delta^{74} \mathrm{Ge}_{\mathrm{pw}}$ trend indicates negligible $\mathrm{Ge}$ isotope fractionation during this process. Ge fluxes measured via core incubations were variable and appeared strongly controlled by Fe redox behavior near the sediment-water interface. In some cases, reductive Fe oxide dissolution appeared to enhance the benthic Ge flux by over $100 \%$ and released fractionated low $\delta^{74} \mathrm{Ge}$ of $\sim-0.7 \%$, resulting in overall benthic $\delta^{74} \mathrm{Ge}_{\text {inc }}$ between -0.2 and $3.6 \%$, depending on Fe oxide contribution to Ge flux. We estimate that detrital inputs supply $12-31 \%$ of total dissolved Ge to continental margin pore fluids globally, resulting in an average pore water and benthic flux $\delta^{74}$ Ge between 2.2 and $2.7 \%$. Assuming 10-60\% of pore water $\mathrm{Ge}$ is captured by the authigenic aluminosilicate sink, the dissolved Ge flux to the ocean derived from terrigenous inputs should be roughly 2.5-6.6 Mmol/y, much higher than previously estimated. Our results imply that authigenic Si burial in continental margins should be in the range of 1-8 Tmol/y (best estimate $3.1 \mathrm{Tmol} / \mathrm{y}$ ), sufficient to close the global marine Si budget.

Keywords: germanium, biogenic silica, authigenesis, Fe oxides, isotope fractionation, continental margin

\section{INTRODUCTION}

Silicon ( $\mathrm{Si}$ ) is a major constituent of Earth's silicate crust that is released to solution during rock weathering and delivered to the ocean by rivers, where it sustains the productivity of marine biosilicifying organisms (Tréguer and De La Rocha, 2013). Oceanic Si concentrations also determine the rate of authigenic clay formation in sediments, which has been proposed to influence 
global climate through its effects on the marine carbonate balance (Mackenzie and Garrels, 1966). Silicon isotope ratio $\left({ }^{30} \mathrm{Si} /{ }^{28} \mathrm{Si}\right.$, expressed as $\left.\delta^{30} \mathrm{Si}\right)$ and the germanium-to-silicon $(\mathrm{Ge} / \mathrm{Si})$ ratio have been developed as proxies tracing the biogeochemical cycling of Si (e.g., Froelich et al., 1985; Murnane and Stallard, 1990; De La Rocha et al., 2000; Ziegler et al., 2005). Recently, the stable isotope composition of $\mathrm{Ge}\left({ }^{74} \mathrm{Ge} /{ }^{70} \mathrm{Ge}\right.$ ratio, expressed as $\delta^{74} \mathrm{Ge}$ ) has been measured in the major Earth surface reservoirs and proposed as an additional proxy helping to constrain the coupled biogeochemical cycles of Ge and Si (Rouxel et al., 2006; Escoube et al., 2012, 2015; Baronas et al., 2017, 2018; Rouxel and Luais, 2017). Germanium is a useful tracer of the Si cycle due to its prevalence in silicate rocks and the similar atomic properties and chemical behavior of the two elements (Burton et al., 1959; Froelich and Andreae, 1981; Rouxel and Luais, 2017). The ranges of $\mathrm{Ge} / \mathrm{Si}$ and especially $\delta^{74} \mathrm{Ge}$ signatures in silicate rocks are relatively narrow (Mortlock and Froelich, 1987; Escoube et al., 2012; Rouxel and Luais, 2017). During continental weathering processes, the precipitation of secondary weathering products such as Al- and Fe-oxides and aluminosilicate clays preferentially incorporates Ge relative to Si (Froelich et al., 1992; Kurtz et al., 2002) and light Ge isotopes preferentially relative to heavy ones, resulting in dissolved river composition that has lower $\mathrm{Ge} / \mathrm{Si}$ but higher $\delta^{74} \mathrm{Ge}$ relative to silicate rocks (Baronas et al., 2018).

The seawater $\mathrm{Ge} / \mathrm{Si}$ and $\delta^{74} \mathrm{Ge}$ composition is primarily controlled by a balance of riverine and hydrothermal inputs and biogenic and authigenic outputs (Elderfield and Schultz, 1996; Hammond et al., 2000; Escoube et al., 2015; Baronas et al., 2017). Although biological $\mathrm{Ge} / \mathrm{Si}$ fractionation is variable, most diatoms appear to discriminate against Ge only when dissolved $\mathrm{Si}$ is depleted below $\sim 10 \mu \mathrm{mol} / \mathrm{L}$ (Sutton et al., 2010; Baronas et al., 2016). Ge/Si ratios are relatively invariable in deep seawater and in diatom biogenic silica (bSi) because nearly all dissolved $\mathrm{Ge}$ and Si upwelled to the photic zone is exported by diatom growth and settling, and most of this export dissolves congruently in deep water (Froelich et al., 1985, 1992; Ellwood and Maher, 2003; Baronas et al., 2016; Guillermic et al., 2017).

The Ge isotopic composition appears to be unfractionated during $\mathrm{Ge}$ incorporation into diatom $\mathrm{bSi}$, although some fractionation may occur during Ge incorporation into the organic cellular material (Mantoura, 2006; Guillermic et al., 2017; Rouxel and Luais, 2017). Because most organic matter is rapidly remineralized in the upper water column, this secondary fractionation should have little effect on sedimentary $\delta^{74} \mathrm{Ge}$ dynamics. In contrast, all siliceous sponge spicules analyzed to date exhibit $\mathrm{Ge} / \mathrm{Si}$ and $\delta^{74} \mathrm{Ge}$ signatures significantly lower than seawater, indicating strong vital effects (Ellwood et al., 2006, 2010; Rouxel et al., 2006; Guillermic et al., 2017). The magnitude of sponge bSi production and burial is not well-known, although it is likely small relative to diatoms (Van Cappellen, 2003), limiting the influence of biological fractionation on global seawater $\mathrm{Ge} / \mathrm{Si}$ and $\delta^{74} \mathrm{Ge}$ composition.

While the burial of diatom bSi has little or no effect on the seawater $\delta^{74} \mathrm{Ge}$ composition, a large portion of bSi reaching the seafloor dissolves at or just below the water-sediment interface, releasing $\mathrm{Ge}$ and $\mathrm{Si}$ into marine pore waters. A range of complex diagenetic reactions take place in marine sediments, including the precipitation of various authigenic clay minerals (e.g., Aller, 2014). These authigenic minerals incorporate $\mathrm{Ge}$ and $\mathrm{Si}$, affecting pore water Ge/Si (Hammond et al., 2000; King et al., 2000; Baronas et al., 2016), $\delta^{30} \mathrm{Si}$ (Ehlert et al., 2016), and possibly $\delta^{74} \mathrm{Ge}$ signatures. Recent studies have suggested that authigenic ("non-opal") burial plays a major role in the global marine cycles of Ge and Si (Baronas et al., 2016, 2017; Rahman et al., 2016, 2017). Indeed, variations in authigenic Ge burial fluxes are likely responsible for the large seawater $\mathrm{Ge} / \mathrm{Si}$ fluctuations over glacial-interglacial cycles (Mortlock et al., 1991; Hammond et al., 2004b; Baronas et al., 2016). A fully constrained global Ge isotope budget and unambiguous interpretation of past $\delta^{74} \mathrm{Ge}$ variations in seawater therefore require knowledge of the chemical and isotopic Ge behavior during marine sediment authigenesis.

Here, we present dissolved $\mathrm{Ge} / \mathrm{Si}, \delta^{74} \mathrm{Ge}$, and various other solute concentration data at three different continental margin sites. Sediment pore water signatures were used to track the potential isotopic fractionation with progressing sediment diagenesis and authigenesis, while sediment core incubation data were used to constrain the net effect of these processes on the benthic flux. Ultimately, Ge isotopes have allowed us to put preliminary quantitative constraints on Ge partitioning between different sources and sinks in the studied sediments.

\section{STUDY SITES}

San Pedro and Santa Monica basins are located in the Southern California continental margin, $\sim 20$ and $\sim 40 \mathrm{~km}$ offshore from Los Angeles, respectively. A detailed description of the geological and oceanographic setting of the Southern California Bight can be found elsewhere (Gorsline, 1992; Hickey, 1992). San Pedro basin has an area of $819 \mathrm{~km}^{2}$ and is $900 \mathrm{~m}$ deep. The Santa Monica basin is 2,225 $\mathrm{km}^{2}$ large and $925 \mathrm{~m}$ deep. Both basins are silled below $725 \mathrm{~m}$ depth, restricting the circulation of bottom water, with periodic flushing every few years (Berelson, 1991). Organic matter remineralization renders the restricted bottom water suboxic in both basins, typically $<9 \mu \mathrm{M} \mathrm{O}_{2}$ in San Pedro basin and $<4 \mu \mathrm{M} \mathrm{O}_{2}$ in Santa Monica basin, resulting in reducing sediment pore waters and limited macrofaunal activity in the benthos (Berelson et al., 1987; Leslie et al., 1990; Gorsline, 1992). In San Pedro basin, minor sediment irrigation and bioturbation may occur at times, whereas Santa Monica basin sediments are finely laminated, indicating lack of macrofaunal activity. Material is supplied to both basins primarily through particle infall from the overlying water column and through nepheloid plume transport (e.g., Collins et al., 2011). The sediments are comprised of $1-4 \% \mathrm{bSi}, 8-10 \% \mathrm{CaCO}_{3}$, and $\sim 4 \%$ organic matter, with the remainder being lithogenic particles (Gorsline, 1992; Cheng et al., 2009).

Additional data are presented from the continental Gulf of Mexico shelf, close to the Mississippi River delta. Ge cycling in the area has been described in detail by Baronas et al. (2016), showing that $\mathrm{Ge} / \mathrm{Si}$ ratios in the region are generally elevated due to contamination from coal ash (Froelich et al., 1985) and that authigenic Ge accounts for about $50 \%$ of total Ge burial in the Gulf of Mexico shelf sediments. In this study, new $\delta^{74} \mathrm{Ge}$ 
data from the two regions are presented and analyzed in the context of previously published pore water concentrations and core incubation results.

\section{METHODS}

\subsection{Sample Collection}

San Pedro basin (SPB) sediment cores were collected on 201409-04 aboard the R/V Yellowfin at the San Pedro Ocean Timeseries (SPOT) study site. SPOT is the site of a multi-year monthly water column sampling campaign (https://dornsife.usc. edu/spot/). Santa Monica basin (SMB) cores were collected on 2012-03-08 aboard the R/V Yellowfin in the central part of the basin (Table 1). The cores were kept on ice before being placed in a $5^{\circ} \mathrm{C}$ cold room within $8 \mathrm{~h}$ from retrieval. For half of the cores, the overlying water was siphoned off while avoiding disturbance of the sediment surface. Then, pore waters were sampled using Rhizons $(0.2 \mu \mathrm{m}$ membrane; Rhizosphere Research Products, The Netherlands). The suction was applied at all depth horizons simultaneously to minimize vertical pore water advection during sampling. The pore waters were collected for up to $24 \mathrm{~h}$. All samples were acidified to $0.1 \mathrm{vol} \%$ with Teflondistilled conc. $\mathrm{HNO}_{3}$ inside the sampling syringe. Another set of cores with overlying water were incubated for several days as described below.

Additional water column samples were collected at SPB and in the Atlantic Ocean in 2014 and previously (Table 1). The SPB samples were collected in Niskin bottles on a CTD rosette aboard R/V Yellowfin, filtered through a $0.2 \mu \mathrm{m}$ pore size filter within $10 \mathrm{~h}$ from retrieval, and acidified prior to analyses. The Atlantic Ocean samples were collected at the Bermuda Atlantic Time Series (BATS) station during the June 2008 GEOTRACES intercalibration cruise aboard the R/V Knorr. Further details are given in Baronas et al. (2017).

The Gulf of Mexico (GoMex) samples were collected in August 2011 during cruise EN-494 aboard the R/V Endeavor. Sediment cores were collected using a multi-corer and seawater samples using Niskin bottles. Pore waters were collected via sectioning under $\mathrm{N}_{2}$ atmosphere and centrifugation. All samples were filtered through $0.2 \mu \mathrm{m}$ membrane and acidified prior to analysis. A detailed description of the GoMex methods is given in Baronas et al. (2016).

\subsection{Core Incubations}

Core incubations were carried out using the method described by Hammond et al. (2004a). Briefly, within $6-8 \mathrm{~h}$ of retrieval, sediment cores with 1-1.5 L of overlying water were capped, placed in a $5^{\circ} \mathrm{C}$ cold room and the water slowly stirred (20-30 rpm) using a suspended magnetic stir bar. During incubations, $10-20 \mathrm{~mL}$ of overlying water was periodically sampled for $\mathrm{Ge}$ and Si concentration analyses using a plastic syringe, while the piston was advanced to keep air out. Although care was taken to avoid air contact during core retrieval and incubations, in some cases a bubble of air was introduced to the overlying water, either during capping or via leakage around piston o-rings during sampling. The samples were immediately filtered through a $0.2 \mu \mathrm{m}$ membrane and acidified prior to analysis. After the incubation was completed, the remaining overlying water was collected via siphoning, filtered through a $0.2 \mu \mathrm{m}$ membrane and acidified prior to $\delta^{74} \mathrm{Ge}$ analyses.

\subsection{Solute Concentration Analyses}

Silicic acid and ammonia concentrations were measured using standard colorimetric techniques (Mullin and Riley, 1955; Bower and Holm-Hansen, 1980) with a precision better than $5 \%$. Ammonia analyses were carried out within $24 \mathrm{~h}$ of sample collection to minimize degassing. Iron and manganese concentrations were analyzed by ICP-MS on a Thermo Scientific Element2 with a precision of $\sim 10 \%$. Sulfate concentrations were measured on a Metrohm Ion Chromatograph. Germanium concentrations were measured using isotope-dilution-hydridegeneration-ICP-MS on a Thermo Scientific Element2, using the method developed by Mortlock and Froelich (1996) and modified by Baronas et al. (2016).

\subsection{Ge Isotope Analyses \\ 3.4.1. Ge Co-precipitation}

Filtered and acidified samples of pore water from similar depths of multiple cores were combined to obtain larger composite samples required for $\delta^{74} \mathrm{Ge}$ analyses. Ge concentrations of individual aliquots were analyzed beforehand to ensure that all cores had similar Ge and Si concentration profiles. Pore water, incubation, and seawater samples ranging from $100 \mathrm{~mL}$ to $9 \mathrm{~L}$ and containing 4-13 ng of Ge were then spiked with a Ge isotope double spike $\left({ }^{73} \mathrm{Ge} /{ }^{70} \mathrm{Ge} \approx 1\right.$, previously calibrated and used by Escoube et al., 2012, 2015; Baronas et al., 2018) in a spike/sample Ge mass ratio of 1-2 and a purified $\mathrm{FeCl}_{3}$ solution to obtain a Fe concentration of $\sim 0.2 \mathrm{mmol} / \mathrm{L}$. The samples were well mixed, and allowed to equilibrate for at least $16 \mathrm{~h}$. Next, $\mathrm{Fe}(\mathrm{OH})_{3}$ flock was precipitated by bubbling pure $\mathrm{NH}_{3}$ gas through the sample until the solution reached a $\mathrm{pH}$ of 8-10. The flock was collected by settling and centrifugation, redissolved in $2 \mathrm{~mL}$ concentrated Teflon-distilled $\mathrm{HNO}_{3}$ and diluted to $10 \mathrm{~mL}$ with ultrapure (18 $M \Omega) \mathrm{H}_{2} \mathrm{O}$. The samples were then dried down, redissolved in 1 $\mathrm{mL}$ concentrated Optima-grade $\mathrm{HF}$ and diluted to $30 \mathrm{~mL}$ with ultrapure $\mathrm{H}_{2} \mathrm{O}$ to obtain a final $1 \mathrm{M} \mathrm{HF}$ solution. They were then purified through anion exchange columns as described below. The procedural blank was determined by processing spiked ultrapure $\mathrm{H}_{2} \mathrm{O}$ and ranged from 0.01 to $0.3 \mathrm{ng} \mathrm{Ge}$.

\subsubsection{Anion-Exchange Chromatographic Separation}

A procedure adapted from Rouxel et al. (2006) and described in detail by Guillermic et al. (2017) and Baronas et al. (2018) was used. All reagents used were either in-house Teflon-distilled or Optima-grade. A $10 \mathrm{~mL}$ column was loaded with $1.8 \mathrm{~mL}$ (wet volume) of BioRad AG1-X8 resin, washed with $10 \mathrm{~mL}$ of $3 \mathrm{M} \mathrm{HNO}_{3}, 0.28 \mathrm{M} \mathrm{HNO}_{3}$, and ultrapure $\mathrm{H}_{2} \mathrm{O}$ in sequence and conditioned with $5 \mathrm{~mL} 1 \mathrm{M} \mathrm{HF}$. Samples in $1 \mathrm{M} \mathrm{HF}$ solution as prepared above were centrifuged to separate insoluble fluorides and $10-29 \mathrm{~mL}$ of the solution was carefully added to columns. The presence or the amount of insoluble fluorides at this stage did not appear to affect the final Ge recovery. The remaining matrix was eluted with $5 \mathrm{~mL}$ of $1 \mathrm{M} \mathrm{HF}$ followed by $3 \mathrm{~mL}$ of ultrapure $\mathrm{H}_{2} \mathrm{O}$, leaving fluorinated $\mathrm{Ge}$ retained on the column. Ge was then 
TABLE 1 | Study site locations and details of seawater samples.

\begin{tabular}{|c|c|c|c|c|c|c|c|c|c|c|c|}
\hline Sample & Station & Date & Lat. $\left({ }^{\circ}\right)$ & Long. $\left({ }^{\circ}\right)$ & $\begin{array}{l}\text { Depth } \\
\text { (m) }\end{array}$ & $\begin{array}{c}\mathrm{Ge} \\
\text { (pmol/L) }\end{array}$ & $\begin{array}{c}\mathrm{Si} \\
(\mu \mathrm{mol} / \mathrm{L})\end{array}$ & $\begin{array}{c}\mathrm{Ge} / \mathrm{Si} \\
(\mu \mathrm{mol} / \mathrm{mol})\end{array}$ & $\begin{array}{c}\delta^{74} \mathrm{Ge} \\
(\%)\end{array}$ & $\begin{array}{c}\mathrm{Fe} \\
(\mu \mathrm{mol} / \mathrm{L})\end{array}$ & $\begin{array}{c}\text { Mn } \\
\text { (nmol/L) }\end{array}$ \\
\hline \multicolumn{12}{|l|}{ Gulf of Mexico } \\
\hline GOM CTD-45-7 & Sta. 9 & 2011-08-15 & 28.97 & -90.40 & 2.3 & 43 & 10 & 4.28 & $2.79 \pm 0.50^{\star}$ & - & - \\
\hline GOM CTD-6 (30 m) & Sta. 1 & 2011-08-01 & 28.59 & -90.54 & 30 & 45 & 25 & 1.84 & $2.13 \pm 0.15$ & - & - \\
\hline GOM-CTD-32-3 & Sta. G & 2011-08-09 & 26.28 & -92.02 & 2121 & 17 & 25 & 0.70 & $3.13 \pm 0.28$ & - & - \\
\hline \multicolumn{12}{|l|}{ San Pedro Basin } \\
\hline SPOT SSW & SPOT & 2014-09-10 & 33.55 & -118.40 & 2 & 1.6 & 1.1 & 1.43 & - & - & - \\
\hline UP-18 & SPOT & 2014-04-23 & 33.55 & -118.40 & 50 & 7.0 & 8.0 & 0.88 & $3.41 \pm 0.25$ & - & - \\
\hline SPOT 500 m & SPOT & - & 33.55 & -118.40 & 500 & 55 & 74 & 0.74 & $3.48 \pm 0.35^{\star}$ & - & - \\
\hline SPOT 885 m & SPOT & 2014-09-10 & 33.55 & -118.40 & 885 & 78 & 105 & 0.74 & $2.97 \pm 0.20$ & - & - \\
\hline MC-2D OLW & SPOT & 2014-09-04 & 33.55 & -118.40 & 885 & 91 & 114 & 0.79 & $3.06 \pm 0.22$ & 1.15 & 75 \\
\hline MC-3D OLW & SPOT & 2014-09-04 & 33.55 & -118.40 & 885 & 82 & 111 & 0.74 & $3.23 \pm 0.28$ & 0.69 & 42 \\
\hline MC-5C OLW & SPOT & 2014-09-04 & 33.55 & -118.40 & 885 & 109 & 125 & 0.87 & $2.90 \pm 0.32$ & 0.11 & 46 \\
\hline MC-1D OLW & SPOT & 2014-09-04 & 33.55 & -118.40 & 885 & 92 & 118 & 0.78 & - & 1.71 & 105 \\
\hline MC-2C OLW & SPOT & 2014-09-04 & 33.55 & -118.40 & 885 & 103 & 120 & 0.85 & - & - & - \\
\hline MC-2A OLW & SPOT & 2014-09-04 & 33.55 & -118.40 & 885 & 89 & 116 & 0.77 & - & - & - \\
\hline \multicolumn{12}{|l|}{ Atlantic } \\
\hline GPrl-19 & BATS & 2011-06-08 & 31.67 & -64.17 & 1000 & 12 & 13 & 0.90 & $3.04 \pm 0.28$ & - & - \\
\hline GDI-30,31/32 & BATS & 2011-06-08 & 31.67 & -64.17 & 2000 & 24 & 17 & 1.36 & $3.68 \pm 0.28$ & - & - \\
\hline GPrl-3 & BATS & 2011-06-08 & 31.67 & -64.17 & 3500 & 27 & 28 & 0.97 & $3.03 \pm 0.50^{\star}$ & - & - \\
\hline
\end{tabular}

Dashes indicate no analyses were done. *Previously published in Baronas et al. (2017).

eluted with $10 \mathrm{~mL} 0.28 \mathrm{M} \mathrm{HNO}_{3}$. If required, the solution was dried down and redissolved in a smaller volume of $0.28 \mathrm{M} \mathrm{HNO}_{3}$ to obtain the $0.5-10 \mathrm{ppb}$ Ge concentration required for isotope measurements. Each column was reused 4-5 times, except when retention of DOC from the previous sample was observed based on the color, in which case the resin was replaced. Ge blanks from reused resin were below detection limit.

Ge recovery ranged from 20 to $90 \%$, with one sample being as low as $8 \%$. Incomplete recovery was most likely due to variable $\mathrm{Ge}$ co-precipitation efficiency with $\mathrm{Fe}(\mathrm{OH})_{3}$ (resulting from variable precipitation rates, final $\mathrm{pH}$, and variable sample matrices, especially DOC concentrations in pore waters), as well as some loss during co-precipitate recovery from the solution. Importantly, incomplete recovery did not affect the measured $\delta^{74} \mathrm{Ge}$ values, as all samples were double-spiked prior to sample preparation.

Seawater contains relatively high concentrations of methylated Ge, which does not participate in the inorganic Ge cycle (Lewis et al., 1985, 1988, 1989). It is therefore important to separate the inorganic and the methylated species prior to $\delta^{74} \mathrm{Ge}$ analysis. Baronas et al. (2017) achieved this via chromatographic separation of the methylated and inorganic Ge hydrides. In this study, separation was achieved during both Fe co-precipitation and anion column chromatography, and is confirmed by the agreement of seawater $\delta^{74} \mathrm{Ge}$ determined via both methods (Table 1).

\subsubsection{HG-MC-ICP-MS}

Ge isotope analyses were performed on a Thermo Neptune multi-collector ICP-MS at Ifremer in Brest, France, using the method of Rouxel et al. (2006) as adapted by Escoube et al. (2015), Guillermic et al. (2017), and Baronas et al. (2018). Sample solutions of $0.5-10 \mathrm{ppb}$ natural $\mathrm{Ge}$ in $0.28 \mathrm{M} \mathrm{HNO}_{3}$ were introduced into an online hydride generation system (CETAC HGX-200) at a rate of $150 \mu \mathrm{L} / \mathrm{min}$ where they were mixed with $0.25 \mathrm{M} \mathrm{NaBH}_{4}$ solution (in $1.5 \mathrm{M} \mathrm{NaOH}$ ) introduced at an equal rate. The dissolved $\mathrm{Ge}(\mathrm{OH})_{4}$ species were reduced to gaseous $\mathrm{GeH}_{4}$ and transported into the ICP-MS torch using Ar carrier gas. The Neptune MC-ICP-MS was operated in low mass resolution mode, measuring ${ }^{70} \mathrm{Ge},{ }^{72} \mathrm{Ge},{ }^{73} \mathrm{Ge}$, and ${ }^{74} \mathrm{Ge}$ in $\mathrm{L} 2$, $\mathrm{C}, \mathrm{H} 1$ and $\mathrm{H} 2$ cups, respectively. In addition, L4, L3, L1, and $\mathrm{H} 4$ cups were also monitored for ${ }^{68} \mathrm{Zn}$ (possible interference as ${ }^{70} \mathrm{Zn}$ ), ${ }^{69} \mathrm{Ga},{ }^{71} \mathrm{Ga}$ (possible interferences at $\mathrm{m} / \mathrm{z} 70$ ), and ${ }^{77} \mathrm{Se}$ (possible interference as ${ }^{74} \mathrm{Se}$ ), respectively. No interferences were detected in any of the runs. The samples were bracketed using a NIST-3120a standard solution that had a total Ge concentration generally within $\sim 20 \%$ of the bracketed sample, and was double-spiked to have a spike/sample ratio within $\sim 20 \%$ of the bracketed sample. Each sample or standard run consisted of 6 measurement blocks each lasting $2 \mathrm{~min}$ (30 cycles of $4 \mathrm{~s}$ each), and in most cases 4-5 blocks displaying the most stable signal were retained. Therefore, each measurement consisted of 8-10 min of counting statistics at signal intensities ranging from 0.4 to $6 \mathrm{~V}(4-60 \mathrm{pA})$ at ${ }^{74} \mathrm{Ge}$ (depending on Ge concentration in sample solution and instrument tuning). Instrumental blank measurements were generally below $2 \%$ of measured sample and standard intensities, suggesting that a wash-out time of $8 \mathrm{~min}$ was sufficient to avoid significant memory effects. The $\delta^{74} \mathrm{Ge}$ values were calculated for each block using the double-spike data reduction routine of Siebert et al. (2001) and are reported in \%o 
as ${ }^{74} \mathrm{Ge} /{ }^{70} \mathrm{Ge}$ sample ratio normalized to the average ${ }^{74} \mathrm{Ge} /{ }^{70} \mathrm{Ge}$ ratio of bracketing measurements of Ge isotope standard NIST 3120a. This method also yields Ge concentration values based on the measured spike/sample ratio. Several different reference materials were analyzed multiple times, interspersed with the samples, and all agreed well with values previously reported by Baronas et al. (2018). The measurement uncertainty is reported as the internal $2 \sigma$ standard error of the used sample blocks, or $2 \sigma$ standard deviation of all NIST 3120a bracketing standard measurements within a given analytical session, whichever is higher.

\section{RESULTS}

All of the Gulf of Mexico (GoMex) data, with the exception of $\delta^{74} \mathrm{Ge}$, were previously reported and discussed by Baronas et al. (2016). This section therefore focuses on the newly acquired data from San Pedro and Santa Monica basins.

\subsection{Seawater}

Seawater data are reported in Table 1. Several samples were previously analyzed for $\delta^{74} \mathrm{Ge}$ by Baronas et al. (2017) and re-analyzed in this study, yielding identical values within analytical uncertainty.

The Ge/Si value determined for SPB bottom seawater (885 $\mathrm{m}$ depth) was $0.74 \mu \mathrm{mol} / \mathrm{mol}$, close to the global ocean value of $0.76 \mu \mathrm{mol} / \mathrm{mol}$ (Froelich et al., 1985; Sutton et al., 2010). Core top water collected up to $8 \mathrm{~h}$ after core retrieval exhibited slightly elevated $\mathrm{Ge}$ and $\mathrm{Si}$ concentrations, with $\mathrm{Ge} / \mathrm{Si}$ up to $0.87 \mu \mathrm{mol} / \mathrm{mol}$. These were likely affected by benthic flux and disturbance during transport. SPB bottom seawater $\delta^{74}$ Ge ranged from 2.9 to $3.2 \%$, slightly lighter than the $3.4-3.5 \%$ determined higher in the water column (Table 1; Baronas et al., 2017), which is indistinguishable from deep seawater $\delta^{74} \mathrm{Ge}$ values in other oceanic basins (Guillermic et al., 2017).

\subsection{Pore Waters}

The pore water solute concentrations were similar in each individual core. Ge concentrations ranged from 90 to 1,200 $\mathrm{pmol} / \mathrm{L}$ (Supplementary Data) and showed a maximum at 2$3 \mathrm{~cm}$ depth, decreasing monotonically below (Figure 1). In contrast, Si concentrations were lowest at the sediment-water interface and increased from $\sim 250$ to $\sim 400 \mu \mathrm{mol} / \mathrm{L}$ within the top $10 \mathrm{~cm}$, with a continued slow increase to $\sim 500 \mu \mathrm{mol} / \mathrm{L}$ by $35 \mathrm{~cm}$ depth (Figure 1). Pore water $\mathrm{Ge} / \mathrm{Si}$ ranged from a high of $2-3 \mu \mathrm{mol} / \mathrm{mol}$ at $2-3 \mathrm{~cm}$ depth to a low of $0.2-0.4$ $\mu \mathrm{mol} / \mathrm{mol}$ at the bottom of the cores. $\delta^{74} \mathrm{Ge}$ values in pore water were lighter than in the water column, ranging from 1.3 to $2.3 \%$ in SPB and SMB and from 1.9 to $2.4 \%$ in GoMex sediments (Table 2). Pore water $\delta^{74} \mathrm{Ge}$ showed little variation with depth.

$\mathrm{Fe}, \mathrm{Mn}, \mathrm{NH}_{3}$, and $\mathrm{SO}_{4}$ concentrations in $\mathrm{SPB}$ pore waters are reported in Figure 1 and Supplementary Data. Fe concentrations ranged from 1 to $300 \mu \mathrm{mol} / \mathrm{L}$, with a maximum at 2-3 cm depth. $\mathrm{Mn}$ and $\mathrm{NH}_{3}$ concentrations ranged from 0 to $600 \mathrm{nmol} / \mathrm{L}$ and from 20 to $400 \mu \mathrm{mol} / \mathrm{L}$, respectively, and both increased monotonically with depth. Fe and Mn concentrations reported here are in good agreement with recently published profiles from ancillary cores collected during this cruise (Monteverde et al., 2018). Sulfate concentrations were in 24-26 $\mathrm{mmol} / \mathrm{L}$ range and appeared to slightly decrease with depth in SPB sediments (previously published by Monteverde et al., 2018).

\subsection{Core Incubations}

Core incubations were performed with core-top water present for up to 6 days, to constrain the net effect of sediment diagenetic processes on the benthic $\mathrm{Ge}$ and $\mathrm{Si}$ fluxes and the $\delta^{74} \mathrm{Ge}$ composition of the benthic flux. Throughout the incubations, Ge concentrations increased from $70-80$ to $80-120 \mathrm{pmol} / \mathrm{L}$ in SPB overlying water and from $90-100$ to $120-150 \mathrm{pmol} / \mathrm{L}$ in SMB overlying water. Si concentrations increased from $\sim 100$ to $130-150 \mu \mathrm{mol} / \mathrm{L}$ in SPB and from $\sim 130$ to $150-190 \mu \mathrm{mol} / \mathrm{L}$ in SMB (Figure 3; Supplementary Data). Table 3 summarizes the chemical and isotopic composition of the post-incubation overlying water and the calculated benthic fluxes. The Ge benthic fluxes were calculated to range from $\sim 0$ to $1.8 \mathrm{nmol} \mathrm{m}^{-2} \mathrm{~d}^{-1}$ at SPB and from 0.9 to $1.5 \mathrm{nmol} \mathrm{m} \mathrm{m}^{-2} \mathrm{~d}^{-1}$ at SMB. The Si benthic fluxes ranged from 0.7 to $1.6 \mathrm{mmol} \mathrm{m}^{-2} \mathrm{~d}^{-1}$ at SPB and from 0.5 to $1.4 \mathrm{mmol} \mathrm{m}^{-2} \mathrm{~d}^{-1}$ at $\mathrm{SMB}$, in good agreement with previous measurements (e.g., Hammond et al., 2000; McManus et al., 2003; Baronas et al., 2016). As a result, the benthic flux $\mathrm{Ge} / \mathrm{Si}$ ratios exhibited a wide range at both sites (0.03-1.1 $\mu \mathrm{mol} / \mathrm{mol}$ at SPB and $0.9-1.8 \mu \mathrm{mol} / \mathrm{mol}$ at SMB). The postincubation $\delta^{74} \mathrm{Ge}$ was in the $2.9-3.5 \%$ o range, similar to the initial overlying composition (2.9-3.2\%o), with the exception of one SPB incubation (MC-3A; $2.07 \pm 0.71 \%$ ) that showed the highest Ge flux.

In the Gulf of Mexico, the $\delta^{74} \mathrm{Ge}$ composition of two post-incubation overlying water samples was determined in addition to previous data reported by Baronas et al. (2017) (Table 3). At Station 1, which is located close to the Mississippi River delta, post-incubation $\delta^{74} \mathrm{Ge}$ was determined to be $2.4 \%$ o (bottom seawater at this site was $2.1 \%$ ), in agreement with data from other cores of Baronas et al. (2017). At Station 2, which was located several hundred kilometers away from the river delta, $\delta^{74} \mathrm{Ge}$ was determined to be $3.4 \%$, similar to the deep seawater in the Gulf of Mexico and other oceanic basins (Table 1; Guillermic et al., 2017).

\section{DISCUSSION}

\subsection{Pore Waters}

Broadly, the $\delta^{74} \mathrm{Ge}$ and $\mathrm{Ge} / \mathrm{Si}$ composition of fluids within and above sediments is controlled by (1) mixing of various solute sources (dissolution of bSi vs. lithogenic particles, as well as trapped/diffusing bottom water); and (2) solute removal via precipitation of authigenic phases (Fe oxides and authigenic aluminosilicates), and associated elemental or isotopic fractionation. Pore water $\delta^{74} \mathrm{Ge}$ measured in SPB and $\mathrm{SMB}$ sediments was $1-2 \%$ lighter than the expected composition of the dissolving diatom bSi, which is likely to be similar to the overlying seawater (Figure 1A). Therefore, the low $\delta^{74} \mathrm{Ge}_{\mathrm{pw}}$ composition must reflect either a significant 

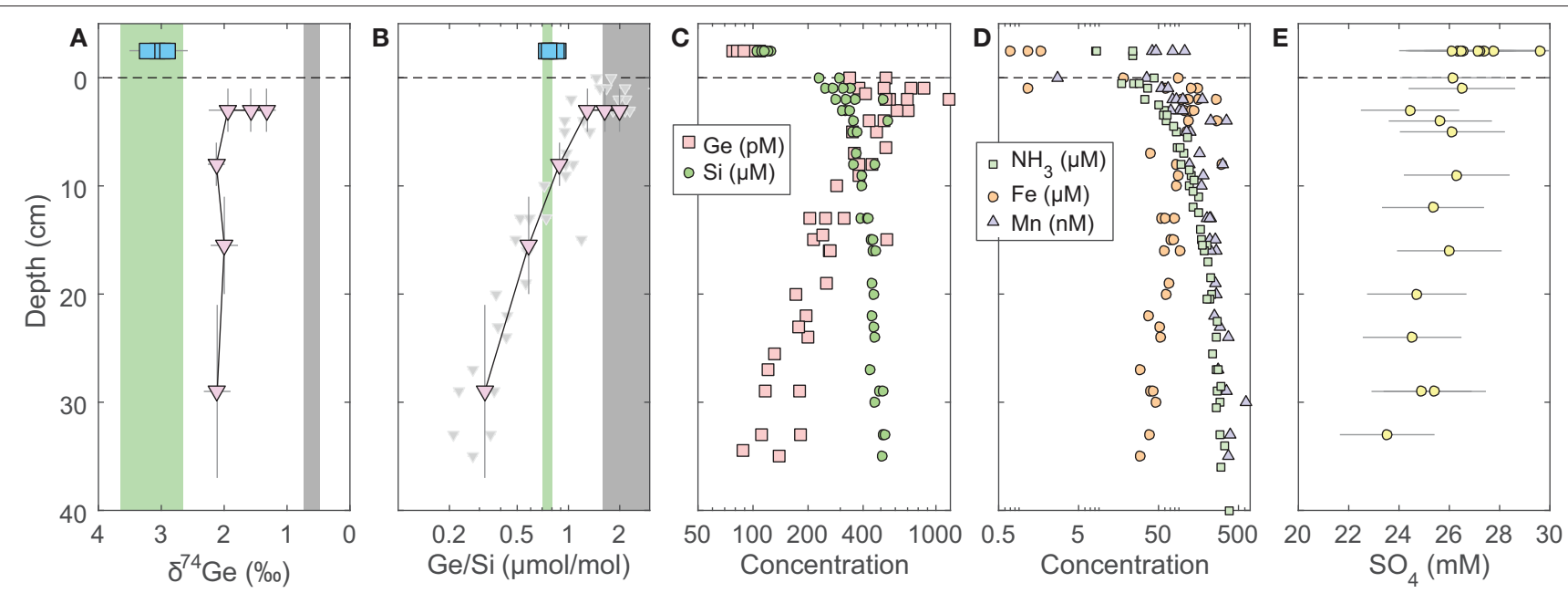

FIGURE 1 | Pore water profiles of San Pedro Basin (SPB) sediments collected from five cores. Bottom seawater and initial core top overlying water data are plotted at an arbitrary depth above the sediment-water interface as blue squares. (A) Ge isotope composition of composite samples; vertical error bars show the depth range of combined samples. Three different composites were measured at the 1-5 cm horizon (see Table 2). Note the reverse X-axis; (B) Ge/Si of composite samples as in (A); also shown are individual sample Ge/Si ratios as small gray triangles. Note the log scale of x-axis. The green band shows the estimated $\delta^{74} \mathrm{Ge}$ and the measured Ge/Si composition of bSi (Baronas et al., 2016), equivalent to seawater. The gray bands show the typical composition of lithogenic silicates (Escoube et al., 2012; Rouxel and Luais, 2017); (C) Ge and Si concentrations; (D) $\mathrm{NH}_{3}$, Fe, and Mn concentrations; (E) Sulfate concentrations from cores MC-1D and MC-2A

(Supplementary Data), uncorrected for potential variations in salinity.

contribution from an isotopically lighter source, or fractionation during Ge incorporation into precipitating authigenic phases. Previous studies have shown that various lithogenic silicates, including marine sediments, exhibit a narrow $\delta^{74} \mathrm{Ge}$ range of $0.4-0.8 \%$ (Rouxel and Luais, 2017). Secondary terrestrial weathering products, for example $\mathrm{Fe}$ oxides, are known to be enriched in Ge (Kurtz et al., 2002) and to preferentially incorporate light $\mathrm{Ge}$ isotopes during formation (Pokrovsky et al., 2014). The $\delta^{74} \mathrm{Ge}$ signature of lithogenic material delivered to the sediments should therefore be close to (potentially slightly lower than) the Bulk Silicate Earth value of $0.58 \pm 0.21 \%$ (Rouxel and Luais, 2017).

In SPB pore waters, the lowest $\delta^{74} \mathrm{Ge}_{\mathrm{pw}}$ values are found in the 1-5 cm depth horizon, coinciding with the highest $\mathrm{Ge} / \mathrm{Si}$ ratios and highest $\mathrm{Fe}$ concentrations in pore waters (Figure 1). Pore water composition in this zone is therefore most likely controlled by mixing of three sources: dissolution of bSi $\left(\mathrm{Ge} / \mathrm{Si}=0.7 \mu \mathrm{mol} / \mathrm{mol} ; \delta^{74} \mathrm{Ge}=3-3.5 \%\right.$ ), dissolution or desorption of $\mathrm{Ge}$ from lithogenic particles $(\mathrm{Ge} / \mathrm{Si} \geqslant$ $1.5 \mu \mathrm{mol} / \mathrm{mol} ; \delta^{74} \mathrm{Ge} \leqslant 0.6 \%$ ), and the reductive dissolution of authigenic Fe oxides that precipitate at the sediment-water interface (Figure 1). Germanium is well-known to adsorb or co-precipitate with Fe (oxy)hydroxides (e.g., Pokrovsky et al., 2006). Indeed, $\mathrm{Fe}$ (oxy)hydroxide (abbreviated as $\mathrm{FeOx}$ from here on) co-precipitation is used to pre-concentrate Ge from dissolved samples during sample preparation (see section 3). This scenario might involve non-steady state Fe redox dynamics in these sediments, which is possible, given the occasional reoxygenation of bottom waters (Berelson, 1991) and the possible introduction of oxygen during core retrieval (see section 5.2). For this reason, further pore water discussion focuses on deeper $(>10$ $\mathrm{cm}$ ) pore waters, which are unaffected by Fe redox dynamics. We will return to the coupling of Ge to Fe redox in the discussion of core incubation data (section 5.2).

\subsubsection{Effect of Authigenic Clay Precipitation on Ge Isotope Composition}

Pore water $\mathrm{Ge} / \mathrm{Si}$ values decrease with depth (Figure 1B), indicating that dissolved $\mathrm{Ge}$ is being removed from pore water via the precipitation of authigenic (non-opal) phases, which has previously been observed in SPB (Hammond et al., 2000; King et al., 2000; McManus et al., 2003). Although the stoichiometry and the mineralogy of the precipitating phases are poorly constrained, the tight coupling of $\mathrm{Ge}$ and $\mathrm{Fe}$ concentrations (Figures 1C,D) suggests it could be Ferich aluminosilicate clays. Such clays have been shown to form rapidly in continental margin environments, including GoMex sediments (Michalopoulos and Aller, 1995; Presti and Michalopoulos, 2008; Rahman et al., 2017). The formation of aluminosilicate clays is also suggested by the asymptotic increase in Si concentrations to $\sim 400-500 \mu \mathrm{mol} / \mathrm{L}$ at $30-40 \mathrm{~cm}$ depth (Table 2, Figures 1; 2; see also Murnane et al., 1989), which are significantly lower than the solubility of bSi, the latter ranging from 600 to $1,000 \mu \mathrm{mol} / \mathrm{L}$, depending on bSi age and the degree of surface passivation by authigenic coatings (e.g., McManus et al., 1995). Very similar dissolved Si profiles have been observed in other regions with high rates of authigenic clay formation (e.g., Michalopoulos and Aller, 1995, 2004; Ehlert et al., 2016).

Isotopically light $\mathrm{Ge}$ is also readily incorporated into sulfide minerals that precipitate in hydrothermal settings, e.g., sphalerite (ZnS) (Luais, 2007, 2012; Escoube et al., 2012, 2015; Belissont et al., 2014; Meng et al., 2015) and possibly during sulfate reduction in marine sediments (Murnane et al., 1989), although the latter has not been clearly demonstrated. Sulfate 
TABLE 2 | Ge and Si chemistry of composite pore waters.

\begin{tabular}{|c|c|c|c|c|c|c|}
\hline Cores & Station & $\begin{array}{c}\text { Depth } \\
\text { (cm) }\end{array}$ & $\begin{array}{c}\mathrm{Ge} \\
\text { (pmol/L) }\end{array}$ & $\begin{array}{c}\mathrm{Si} \\
(\mu \mathrm{mol} / \mathrm{L})\end{array}$ & $\begin{array}{c}\mathrm{Ge} / \mathrm{Si} \\
(\mu \mathrm{mol} / \mathrm{mol})\end{array}$ & $\begin{array}{c}\delta^{74} \mathrm{Ge} \\
(\% 0)\end{array}$ \\
\hline \multicolumn{7}{|l|}{ San Pedro Basin } \\
\hline MC-2A, MC-2C, MC-2D & SPOT & $1-5$ & 568 & 347 & 1.64 & $1.33 \pm 0.15$ \\
\hline MC-1D, MC-3D & SPOT & $1-5$ & 595 & 298 & 1.99 & $1.58 \pm 0.16$ \\
\hline MC-5C (C-1, C-2) & SPOT & $1-5$ & 595 & 460 & 1.29 & $1.94 \pm 0.31$ \\
\hline MC-1D- MC-5C (all cores) & SPOT & $6-10$ & 346 & 391 & 0.89 & $2.12 \pm 0.13$ \\
\hline MC-1D- MC-5C (all cores) & SPOT & $11-20$ & 251 & 430 & 0.58 & $2.00 \pm 0.22$ \\
\hline MC-1D- MC-5C (all cores) & SPOT & $21-37$ & 147 & 455 & 0.32 & $2.11 \pm 0.21$ \\
\hline$M C-2 A$ & SPOT & 0 & 531 & 297 & 1.78 & - \\
\hline $\mathrm{MC}-2 \mathrm{~A}$ & SPOT & 8 & 380 & 356 & 1.07 & - \\
\hline MC-2A & SPOT & 15 & 214 & 440 & 0.49 & - \\
\hline$M C-2 A$ & SPOT & 33 & 111 & 525 & 0.21 & - \\
\hline \multicolumn{7}{|l|}{ Santa Monica Basin } \\
\hline D1-S2, D1-S4, D3-S1, D3-S3 & $\mathrm{SMB}$ & $4-6$ & 379 & 366 & 1.03 & $2.30 \pm 0.28$ \\
\hline \multicolumn{7}{|l|}{ Gulf of Mexico* } \\
\hline MC-6C, MC6-D, MC6-E & Sta. 2 & $0-3$ & 386 & 313 & 1.23 & $2.29 \pm 0.42$ \\
\hline MC-6C, MC6-D, MC6-E & Sta. 2 & $3-6$ & 639 & 462 & 1.38 & $2.44 \pm 0.16$ \\
\hline MC-6C, MC6-D MC6-E & Sta. 2 & $6-10$ & 517 & 521 & 0.99 & $2.12 \pm 0.32$ \\
\hline MC-6C, MC6-D, MC6-E & Sta. 2 & $10-15$ & 326 & 520 & 0.63 & $2.03 \pm 0.32$ \\
\hline MC-6C, MC6-D, MC6-E & Sta. 2 & $15-20$ & 385 & 435 & 0.88 & $1.94 \pm 0.32$ \\
\hline
\end{tabular}

Individual high resolution sample measurements are given in Supplementary Data. *All Gulf of Mexico data except $\delta^{74}$ Ge were previously published in Baronas et al. (2016).

TABLE 3 | Summary of core incubation data, showing the final post-incubation composition of the overlying water, as well as the calculated Ge and Si fluxes.

\begin{tabular}{|c|c|c|c|c|c|c|c|c|}
\hline \multirow[b]{2}{*}{ Cores } & \multirow[b]{2}{*}{ Station } & \multicolumn{4}{|c|}{ final composition after incubation } & \multirow[b]{2}{*}{$\begin{array}{l}\text { Ge flux (nmol } \\
m^{-2} d^{-1} \text { ) }\end{array}$} & \multirow[b]{2}{*}{$\begin{array}{c}\text { Si flux (mmol } \\
\left.\mathrm{m}^{-2} \mathrm{~d}^{-1}\right)\end{array}$} & \multirow[b]{2}{*}{$\begin{array}{c}\text { Ge/Si flux } \\
\text { ( } \mu \mathrm{mol} / \mathrm{mol})\end{array}$} \\
\hline & & $\begin{array}{c}\mathrm{Ge} \\
(\mathrm{pmol} / \mathrm{L})\end{array}$ & $\begin{array}{c}\mathrm{Si} \\
(\mu \mathrm{mol} / \mathrm{L})\end{array}$ & $\begin{array}{c}\mathrm{Ge} / \mathrm{Si} \\
(\mu \mathrm{mol} / \mathrm{mol})\end{array}$ & $\delta^{74} \mathrm{Ge}(\%)$ & & & \\
\hline \multicolumn{9}{|l|}{ San Pedro Basin } \\
\hline MG-3A & SPOT & 118 & 142 & 0.83 & $2.07 \pm 0.71$ & 1.78 & 1.59 & 1.12 \\
\hline$M G-4 C^{\#}$ & SPOT & 110 & 149 & 0.74 & $2.93 \pm 0.28$ & 0.50 & 0.75 & 0.67 \\
\hline$M G-5 A^{\#}$ & SPOT & 90 & 156 & 0.58 & $3.53 \pm 0.28$ & 0.02 & 0.73 & 0.03 \\
\hline MG-5B & SPOT & 80 & 144 & 0.55 & $3.14 \pm 0.28$ & 0.43 & 0.77 & 0.56 \\
\hline$M G-5 D^{\#}$ & SPOT & 98 & 129 & 0.76 & $3.38 \pm 0.18$ & 0.41 & 0.98 & 0.41 \\
\hline \multicolumn{9}{|c|}{ Santa Monica Basin } \\
\hline D3-S2 & $\mathrm{SMB}$ & 145 & 154 & 0.95 & $3.26 \pm 0.28$ & 0.91 & 0.50 & 1.81 \\
\hline D4-S1 & SMB & 147 & 165 & 0.89 & - & 1.12 & 0.75 & 1.49 \\
\hline D4-S4 & $\mathrm{SMB}$ & 147 & 170 & 0.86 & $3.42 \pm 0.28$ & 0.87 & 0.70 & 1.24 \\
\hline D5-S1 & $\mathrm{SMB}$ & 151 & 189 & 0.80 & $2.95 \pm 0.28$ & 1.48 & 1.43 & 1.04 \\
\hline D5-S4 & $\mathrm{SMB}$ & 116 & 163 & 0.71 & - & 0.90 & 1.00 & 0.90 \\
\hline \multicolumn{9}{|l|}{ Gulf of Mexico } \\
\hline$M G-2 A^{*}$ & Sta. 1 & 111 & 70 & 1.59 & $2.71 \pm 0.50$ & 2.17 & 2.09 & 1.04 \\
\hline MG-2B & Sta. 1 & 99 & 58 & 1.70 & $2.43 \pm 0.28$ & 2.28 & 1.65 & 1.38 \\
\hline$M G-3 A^{*}$ & Sta. 1 & 113 & 83 & 1.35 & $2.36 \pm 0.50$ & 4.09 & 2.65 & 1.54 \\
\hline MG-3B* & Sta. 1 & 113 & 89 & 1.27 & $2.18 \pm 0.50$ & 3.55 & 2.43 & 1.46 \\
\hline MG-6A, MC-6B & Sta. 2 & 58 & 73 & 0.79 & $3.44 \pm 0.24$ & - & 1.97 & - \\
\hline
\end{tabular}

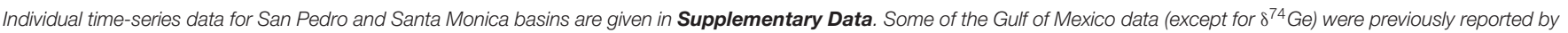
Baronas et al. (2016). Ge and Si flux uncertainties are $20 \%$.

${ }^{*}$ Previously published in Baronas et al. (2017). Water depth is 30-38 $m$ at Sta. 1 and 22-24 $m$ at Sta. 2.

\#A notable air bubble was introduced during recovery or incubation for these cores.

concentration in SPB pore waters decreases slightly with depth (Figure 1E), indicating likely sulfate reduction. Leslie et al. (1990) previously argued that sulfate reduction and pyrite precipitation rates decrease with depth in SPB sediments. Therefore, if pyrite precipitation fractionates $\delta^{74} \mathrm{Ge}$ while sequestering a significant fraction of $\mathrm{Ge}$, we would expect to see a strong $\delta^{74} \mathrm{Ge}_{\mathrm{pw}}$ 
gradient. Such a gradient is not observed (Figure 1A). Overall, authigenic Ge sequestration appears to be independent of sulfide precipitation in this and other continental margins (Hammond et al., 2000; Baronas et al., 2016), which might be due to a low Ge partitioning coefficient into iron sulfides, as suggested by relatively low, sub-ppm Ge concentrations in such minerals (Burton et al., 1959). Pyrite formation is therefore unlikely to be a major factor regulating dissolved Ge dynamics in the sediments studied here.

Regardless of the exact phase, the fraction of dissolved Ge removed from pore waters via authigenesis can be calculated from the change in pore water $\mathrm{Ge} / \mathrm{Si}$ composition with depth. Given that in SPB about half of Ge is supplied via bSi and the other half by lithogenic particles (see section 5.2.2), the $\mathrm{Ge} / \mathrm{Si}$ signature supplied to pore waters should be within 1.0$1.8 \mu \mathrm{mol} / \mathrm{mol}$. Therefore, $\sim 80-90 \%$ of the pore water Ge has to be precipitated to achieve the measured $\mathrm{Ge} / \mathrm{Si}_{\mathrm{pw}}$ of $0.2-0.3$ $\mu \mathrm{mol} / \mathrm{mol}$ by $30 \mathrm{~cm}$ depth. This fraction is slightly higher than previously estimated values of 50-60\% which had not accounted for lithogenic Ge supply (Hammond et al., 2000; Baronas et al., 2016). Note that a significant portion of dissolved Ge diffuses back into overlying water, and therefore the fraction of the total Ge rain to the sediments captured by the authigenic phase is lower (see section 5.2.2). A key take-away from pore water data is that although $80-90 \%$ of dissolved Ge is precipitated by 30 $\mathrm{cm}$ depth, the $\delta^{74} \mathrm{Ge}_{\mathrm{pw}}$ composition remains constant, indicating that any isotopic fractionation during this process is small $(-0.3$ $<\Delta^{74} \mathrm{Ge}_{\text {auth-diss }}<0.3 \%$ ) .

Although the geochemical setting is more complicated and there are fewer data available, the same conclusion can be drawn from the GoMex pore waters (Figure 2). Here, $\delta^{74} \mathrm{Ge}_{\mathrm{pw}}$ is also relatively constant in the $1.9-2.4 \%$ range, whereas $\mathrm{Ge} / \mathrm{Si}$ varies between 1.4 and $0.6 \mu \mathrm{mol} / \mathrm{mol}$, generally decreasing with depth. The Mississippi River supplies a large amount of $\mathrm{Ge}$ and $\mathrm{Si}$ to the studied area, partly due to contamination by anthropogenic activity (Mississippi Ge $/ \mathrm{Si}=1.6 \mu \mathrm{mol} / \mathrm{mol}$; $\delta^{74} \mathrm{Ge}=2.0 \%$; Baronas et al., 2017). Its discharge and possibly chemical and isotopic composition varies temporally, as a result variably affecting the elemental and isotopic composition of diatom bSi that is supplied to and dissolves in the GoMex shelf sediments. Despite the uncertainty of the bSi end-member, the large decrease in pore water $\mathrm{Ge} / \mathrm{Si}$ can only be explained by authigenic Ge precipitation (Baronas et al., 2016). Yet, similarly to SPB sediments, no detectable variation of $\delta^{74} \mathrm{Ge}_{\mathrm{pw}}$ with depth is observed at GoMex (Figure 2A).

We do acknowledge the possibility that the dissolution of several phases (bSi, detrital oxides and silicates) and the precipitation of several others $\left(\mathrm{FeS}_{x}, \mathrm{FeOx}\right.$, authigenic silicates) could fractionate $\delta^{74} \mathrm{Ge}_{\mathrm{pw}}$ in opposite directions, theoretically resulting in the relatively constant $\delta^{74} \mathrm{Ge}_{\mathrm{pw}}$ of about $2 \%$. Assessing this possibility is, however, outside of the scope of this paper and we therefore argue that the simplest explanationno $\delta^{74} \mathrm{Ge}$ fractionation during authigenic phase precipitation-is most likely to be the correct one, especially given the consistency of $\delta^{74} \mathrm{Ge}_{\mathrm{pw}}$ across both (SPB and GoMex) study sites.

Given that secondary clay formation during terrestrial weathering fractionates $\delta^{74} \mathrm{Ge}$ (Baronas et al., 2018; Qi et al.,
2019), it is somewhat surprising that authigenic clay formation in continental margin sediments studied here does not appear to do so. Additional studies are needed to investigate Ge fractionation in these environments in detail; at the moment we can only speculate on the cause of this distinction. Possible reasons include the likely differences in mineralogy of the clays forming in terrestrial and marine environments (e.g., kaolinite vs. glauconite) and the redox conditions (oxic in saprolite, reducing in continental margin sediments), given that $\mathrm{Fe}$ oxides are known to strongly fractionate $\delta^{74} \mathrm{Ge}$ (Pokrovsky et al., 2014, also see discussion below). Another possibility is that Ge isotope fractionation by clays is dominantly kinetic, and in the diffusiondominated reducing sediments, authigenic clays are able to isotopically re-equilibrate with pore waters, erasing any such kinetic fractionation. In contrast, during continental weathering solute transport is dominated by advection (percolation of rain water through soil and saprolite), which limits the time for potential isotopic equilibration between secondary clays and dissolved Ge. Future studies are needed to test these hypotheses.

\subsection{Core Incubations}

Benthic flux measurements reflect the composition of solutes diffusing into the overlying water column, integrating the net effect of all sedimentary processes. Core incubation data can therefore be used to more quantitatively assess the various sources of dissolved Ge to pore waters and the potential isotopic fractionation associated with authigenic phase formation.

\subsubsection{Ge and Si Benthic Fluxes}

The benthic Si fluxes were similar at SPB and SMB sites and individual core experiments agreed well with each other at a given site (relative standard deviation of $\sim 40 \%$; Table 3; Figure 3). In contrast, Ge fluxes differed significantly between the two sites and were especially variable within SPB, spanning two orders of magnitude and resulting in a wide range of observed benthic flux $\mathrm{Ge} / \mathrm{Si}$ ratios. We propose that $\mathrm{Ge}$ fluxes in these experiments were affected by variable redox conditions in the sediments that were perturbed during retrieval, transportation, and incubation.

Santa Monica basin bottom waters and sediments are known to be consistently anoxic, exhibiting high benthic Fe flux and dissolved $\mathrm{Fe}^{2+}$ up to (or nearly up to) the sediment-water interface (McManus et al., 1997; Elrod, 2004; Severmann et al., 2010). The Ge/Si flux at SMB was significantly higher than the $0.7 \mu \mathrm{mol} / \mathrm{mol}$ of dissolving bSi in all cases (Figure 3; Table 3), consistent with the dissolution of Ge-enriched Fe oxides.

At SPB, benthic Ge fluxes and Ge/Si ratios varied widely, the latter ranging from $\sim 0.03$ to $1.12 \mu \mathrm{mol} / \mathrm{mol}$ (Figure 3; Table 3). Considering that all cores were collected in close proximity (cores MC-5A, -5B, and $-5 \mathrm{D}$ were collected during a single multicorer deployment), this variability is unlikely to be caused by spatial heterogeneity in surface sediment composition. The wide range of observed fluxes therefore probably results from the perturbation of bottom redox conditions during core recovery and incubation. It is unavoidable that some oxygen is introduced during sampling. As a result, dissolved $\mathrm{Fe}^{2+}$ in the overlying water and the surficial pore water can be oxidized, capturing a portion (or all, in the case of MC-5A) of the potential Ge 


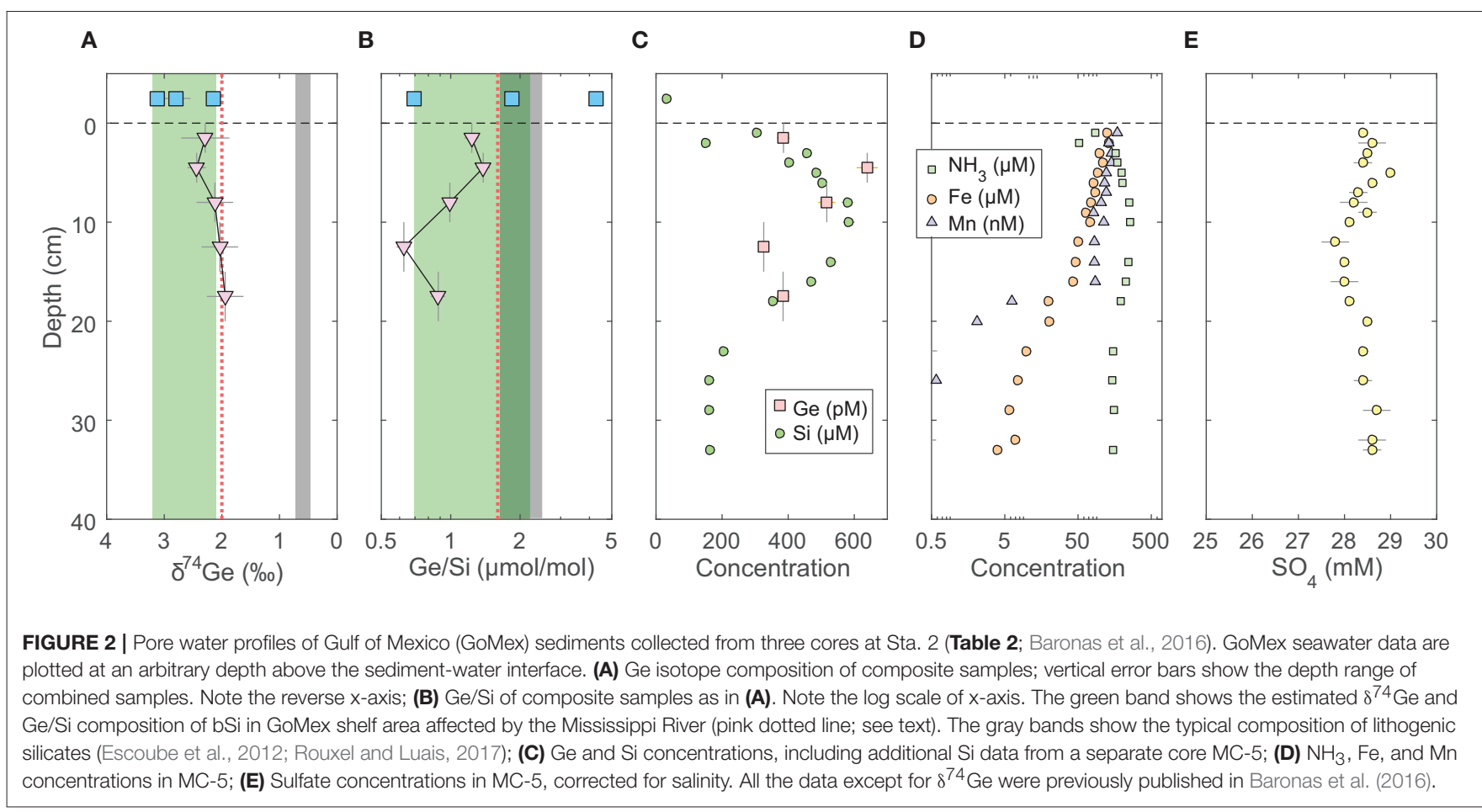

benthic flux. Orange, most likely FeOx, flock was observed on sediment surface of most cores. In addition, core MC-5A, which had negligible benthic Ge flux, also had a large burrow at the sediment water interface and seemed the most disturbed during recovery, including air bubbles trapped in the core liner. In support of this hypothesis, the benthic dissolved Fe flux at SPB was previously determined by in-situ incubations and water column measurements to often be 1-2 orders of magnitude lower than that based on pore water Fe gradients, suggesting that a large fraction of dissolved Fe is captured near the water-sediment interface (Elrod, 2004; Severmann et al., 2010; John et al., 2012).

In summary, the core incubations performed on SPB and SMB sediments together represent a range of bottom redox conditions. Such sampling-induced perturbation provides an independent test of any $\delta^{74} \mathrm{Ge}$ fractionation potentially associated with $\mathrm{Fe}$ oxide precipitation in marine sediments. Below, we perform some simple mass balance modeling to determine benthic flux $\delta^{74} \mathrm{Ge}$ signature of each core and the fraction of Ge released or sequestered by the various solid phases.

\subsubsection{Modeling Ge Isotope Mass Balance During Core Incubations}

Although the large amount of seawater needed for $\delta^{74} \mathrm{Ge}$ analyses prevents the collection of $\delta^{74} \mathrm{Ge}$ time-series data during core incubations, the final post-incubation $\delta^{74} \mathrm{Ge}$ signature $\left(\delta^{74} \mathrm{Ge}_{\text {final }}\right)$ can be used to assess the isotopic composition of Ge flux that has been affected by non-opal phases. To do this, a simple mass balance model was built, partitioning Ge amounts dissolved and sequestered by the various phases, and their associated Ge isotope signatures (Figure 4). The model was implemented using MATLAB R2018b, and the source code is given in the Supplementary Material.

For each incubated sediment core, the amount of $\mathrm{Ge}\left(n_{i}\right.$, in $\mathrm{mol}$ ) in the overlying post-incubation water is the sum of $\mathrm{Ge}$ initially present prior to the incubation and the net added via the benthic flux during incubation:

$$
\begin{aligned}
\mathrm{n}_{\text {final }} & =\mathrm{n}_{\text {initial }}+\mathrm{n}_{\text {inc }} \\
\mathrm{n}_{\text {initial }} & =[\mathrm{Ge}]_{\text {initial }} \cdot \mathrm{V}_{\text {initial }} \\
\mathrm{n}_{\text {inc }} & =\mathrm{F}_{\text {inc }} \cdot \mathrm{t} \cdot \mathrm{A}
\end{aligned}
$$

where $[\mathrm{Ge}]_{\text {initial }}$ and $\mathrm{V}_{\text {initial }}$ are the measured Ge concentration and volume of the pre-incubation overlying water. $F_{\text {inc }}$ is the measured Ge incubation flux given in Table 3 (in mol m$~^{-2}$ time $\left.^{-1}\right), \mathrm{t}$ is incubation time and $\mathrm{A}$ is the core sediment surface area (in $\mathrm{m}^{2}$ ). The $\mathrm{Ge}$ isotope composition in the final post-incubation overlying water is then

$$
\delta_{\text {final }}^{74}=\frac{\mathrm{n}_{\text {initial }} \cdot \delta^{74} \mathrm{Ge}_{\text {initial }}+\mathrm{n}_{\text {inc }} \cdot \delta^{74} \mathrm{Ge}_{\text {inc }}}{\mathrm{n}_{\text {final }}}
$$

Having measured all the other parameters, Equation (4) can be used to calculate $\delta^{74} \mathrm{Ge}_{\text {inc }}$, the isotopic composition of $\mathrm{Ge}$ released into the overlying water during the incubation. Using a number of additional observations and assumptions (see below), we can quantify the different processes controlling the dissolved Ge isotope mass balance in these sediments: (1) Ge release from $\mathrm{bSi}$ and lithogenic particle dissolution ( $\mathrm{F}_{\mathrm{lith}}$ and $\mathrm{F}_{\mathrm{bSi}}$, respectively), followed by (2) the removal or addition of Ge by $\mathrm{Fe}$ redox reactions near the sediment-water interface $\left(\mathrm{F}_{\mathrm{FeOx}}\right)$, 

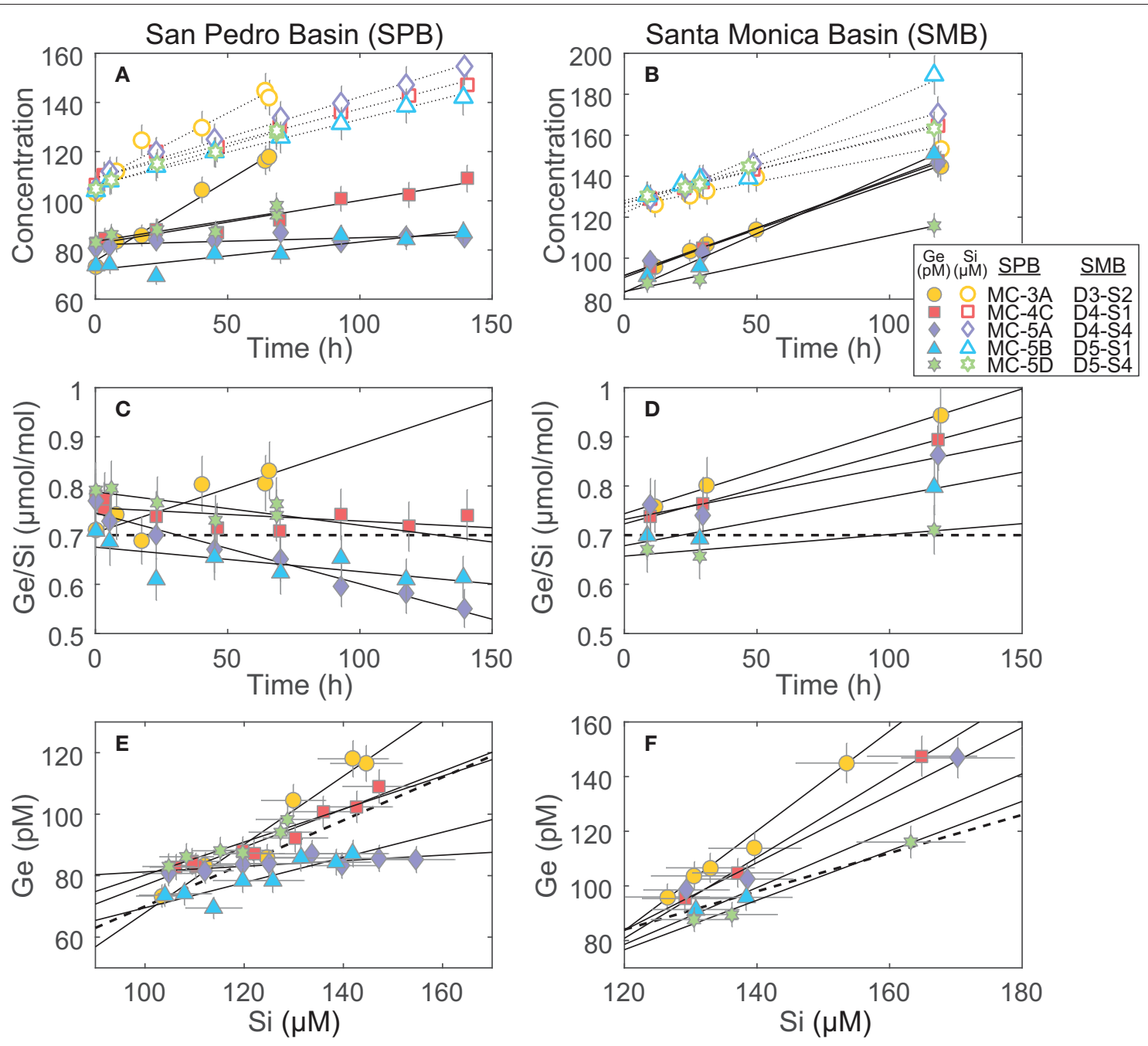

FIGURE 3 | Incubation results of cores from San Pedro and Santa Monica basins (SPB and SMB, respectively): (A,B) The increase of Ge and Si concentrations in the incubated overlying water. These slopes, once corrected for water loss via sampling (see Supplementary Data), were used to determine the benthic Ge and Si fluxes reported in Table 3; (C,D) The change in the Ge/Si ratio of the overlying water. The thick dashed line shows the Ge/Si of biogenic silica in the SPB and SMB sediments (0.7 $\mu \mathrm{mol} / \mathrm{mol}$; Baronas et al., 2016); (E,F) plots showing Ge vs. Si concentration over the course of the incubations. These slopes were used to calculate the benthic flux Ge/Si ratio (Table 3). The thick dashed line shows $\mathrm{Ge} / \mathrm{Si}$ of biogenic silica $(0.7 \mu \mathrm{mol} / \mathrm{mol})$.

and (3) continued removal of Ge by other authigenic phases in deeper sediments $\left(\mathrm{F}_{\text {auth }}\right)$, as observed in the pore water profiles (Figure 4). A Monte Carlo approach (running the model 1 million times for each incubated core) was utilized to assess the full range of uncertainty associated with all the input parameters, yielding probability distributions of the calculated values.

A detailed description of model equations and input parameters is given in section 5.2.2.1. The model results for each individual core are given in Supplementary Material. Here we provide a summary of the overall results.

The combined model results of all eight incubated SPB and SMB cores are given in Table 4 and Figure 5. Based on the measured benthic Si flux (combined with diatom Ge/Si ratio) and lithogenic FeOx input flux (Leslie et al., 1990) we show that the biogenic and lithogenic Ge input fluxes are roughly similar (Figure 5E). Using the $\Delta^{74} \mathrm{Ge}_{\mathrm{FeO} \text {-diss }}$ fractionation factors reported by Pokrovsky et al. (2014) along with the $\delta^{74} \mathrm{Ge}_{\mathrm{pw}}$ data reported here, we calculate that on average, authigenic Ge sequestration takes up between 8 and $41 \%$ of the total allogenic supply ( $f_{\text {auth }}$ between -0.08 and -0.41 ; Table 4; Figure 5C), whereas iron (oxy)hydroxides in most cases sequester a similar proportion of $\mathrm{Ge}\left(f_{\mathrm{FeO}}\right.$ down to -0.5$)$ but in some cases can also release authigenic Ge during dissimilatory $\mathrm{Fe}$ reduction $\left(f_{\mathrm{FeO} x}>0\right)$. This variability in $f_{\mathrm{FeO}}$ is consistent with the qualitative discussion of variable Fe redox dynamics and their perturbation during recovery and is discussed in more detail below.

For SMB cores, the fraction of allogenic Ge input that is captured by authigenic phases is relatively constant, ranging from 14 to $29 \%$ (median $f_{\text {released }}$ between 0.71 and 0.86 ; 


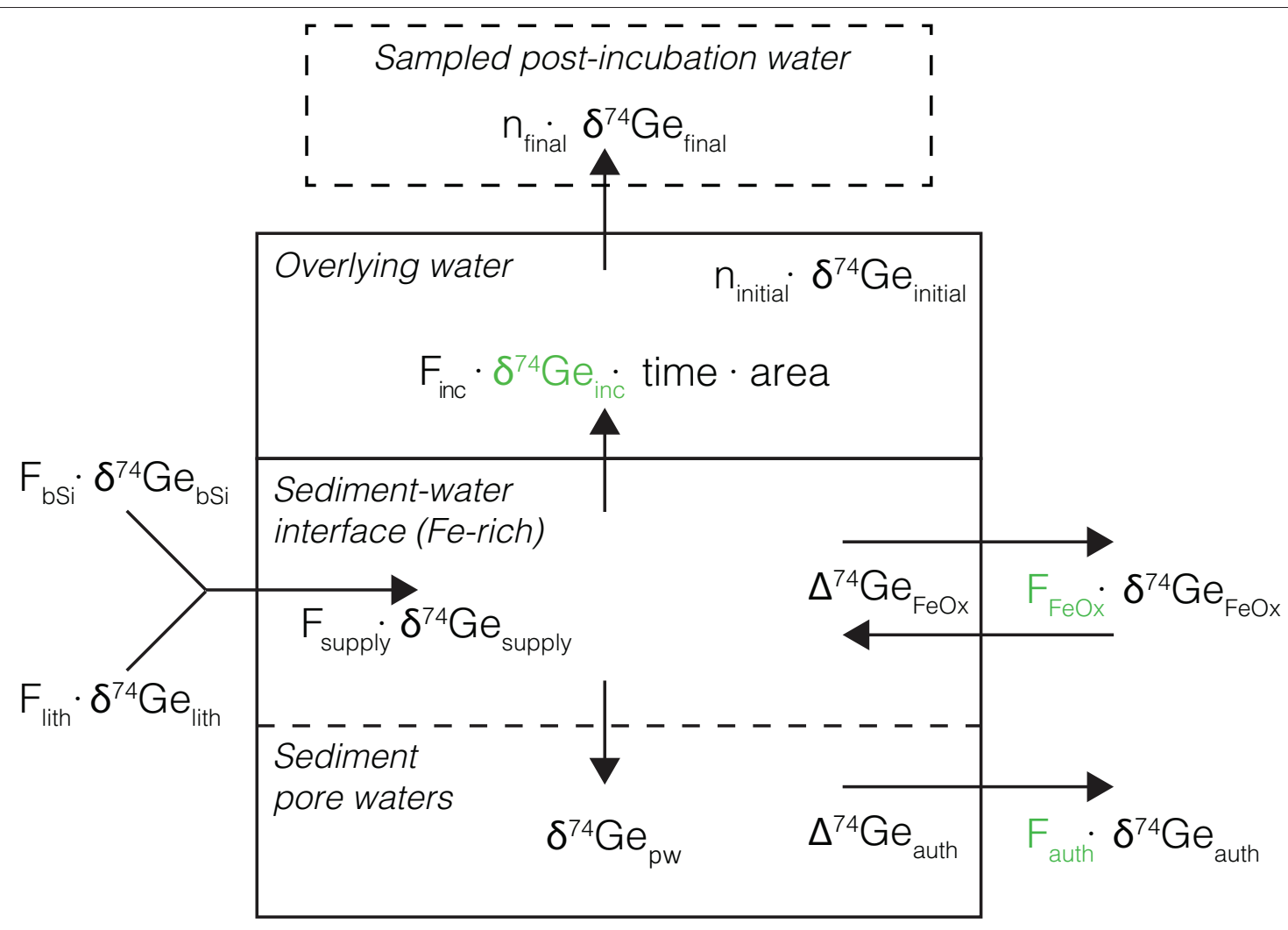

FIGURE 4 | Schematic representation of the Ge isotope mass balance model used to interpret core incubation data. The main model-calculated parameters (namely $\delta^{74} \mathrm{Ge}_{\text {inc }}, F_{\text {auth }}$, and $F_{F e O x}$ ) are shown in green. Other values are either measured or calculated as described in text. Back-diffusion of Ge from overlying water into the sediments is assumed to be small and is ignored.

TABLE 4 | Summary of core incubation model results, combined for all studied cores.

\begin{tabular}{lcc}
\hline Parameter & Median & 25-75th percentile \\
\hline $\mathrm{f}_{\text {lith }}$ & 0.53 & $(0.45$ to 0.59$)$ \\
$\mathrm{f}_{b S i}$ & 0.47 & $(0.41$ to 0.55$)$ \\
$\mathrm{f}_{\text {auth }}$ & -0.20 & $(-0.41$ to -0.08$)$ \\
$\mathrm{f}_{\mathrm{FeOx}}$ & -0.20 & $(-0.50$ to 0.10$)$ \\
$\mathrm{f}_{\text {released }}$ & 0.54 & $(0.31$ to 0.85$)$ \\
$\delta^{74} \mathrm{Ge}_{\text {supply }}(\%)$ & 1.88 & $(1.69$ to 2.11$)$ \\
$\delta^{74} \mathrm{Ge}_{\text {auth }}(\%)$ & 2.13 & $(1.92$ to 2.34$)$ \\
$\delta^{74} \mathrm{Ge}_{\mathrm{FeOx}}(\%)$ & -0.66 & $(-1.32$ to -0.18$)$ \\
$\delta^{74} \mathrm{Ge}_{\text {inc }}(\%)$ & 1.59 & $(0.80$ to 2.39$)$ \\
\hline
\end{tabular}

The ranges given are the 25-75th percentiles of all Monte Carlo calculated values. SPB core $\mathrm{MC}-5 \mathrm{~A}$ is not included in the reported combined $\delta^{74} \mathrm{Ge}_{\text {inc }}$ statistics due to very low benthic Ge flux and the resulting very high uncertainty of the calculated $\delta^{74} \mathrm{Ge}_{\text {inc }}$.

Supplementary Material). Our modeling indicates that authigenic phases play a relatively minor role in SMB sediments $\left(-0.19<f_{\text {auth }}<-0.1\right.$ and $\left.-0.17<f_{\mathrm{FeO} x}<0.07\right)$. While SPB sediments exhibited similar Ge sequestration by the deep (possibly clay) authigenic phase $\left(-0.23<f_{\text {auth }}<-0.16\right.$ with the exception of MC-3A where median $f_{\text {auth }}=-0.81$ ), dissolved Ge uptake or release by authigenic Fe oxides was much more variable $\left(-0.75<f_{\mathrm{FeO}}<0.80\right)$ at $\mathrm{SPB}$, likely caused by perturbations and variable oxygen introduction during core retrieval and incubation (Table 3). As a result, the net fraction of dissolved Ge released back into overlying waters, varied widely among SPB core incubations $\left(f_{\text {released }}=0.02-0.98\right)$. Below we give a detailed description of how these different estimates were calculated.

\subsubsection{Detailed core incubation model description}

Having measured the pre- and post-incubation overlying water $\delta^{74} \mathrm{Ge}$, Equation (4) allows the calculation of $\delta^{74} \mathrm{Ge}_{\text {inc }}$, or the Ge isotope composition of the incubation flux. Here we describe the subsequent calculations used to partition this flux between the different Ge sources and sinks in the incubated sediments. All input parameter values and their uncertainty ranges are given in Supplementary Material.

First, the Ge benthic flux expected from bSi dissolution was calculated simply as

$$
\mathrm{F}_{\mathrm{bSi}}=\mathrm{F}_{\mathrm{inc}}^{\mathrm{Si}} \cdot \mathrm{Ge} / \mathrm{Si}_{\mathrm{bSi}}
$$

which assumes that the amount of the benthic Si flux $\left(\mathrm{F}_{\text {inc }}^{\mathrm{Si}}\right)$ captured by sediment authigenesis is negligible (e.g. less than $10 \%)$. This assumption is validated by the good agreement between the average annual measured $\mathrm{F}_{\text {inc }}^{\mathrm{Si}}$ flux of $1.2 \pm$ 

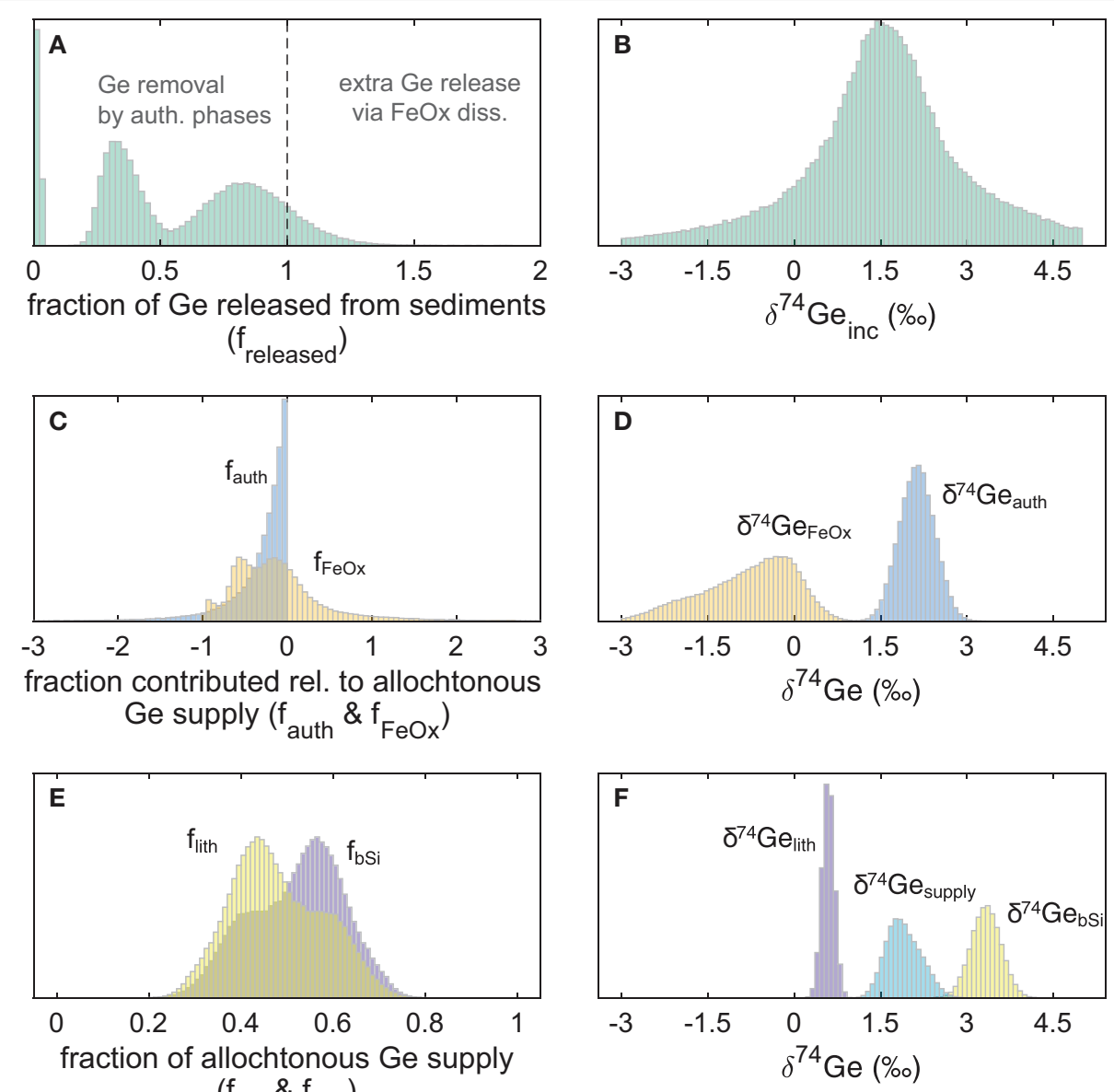

FIGURE 5 | Probability distributions of the fraction of Ge released or consumed by different phases (relative to the allogenic supply from bSi and lithogenic inputs) during San Pedro and Santa Monica basin core incubation experiments, and their isotopic compositions: (A) $f_{\text {released }}$ values < 1 indicate net Ge sequestration in sediments, and values $>1$ indicate additional Ge release from authigenic Fe oxide reduction; (B) the combined probability distribution of $\delta^{74}$ Ge released during all eight core incubations; (C) fraction of Ge consumed $(<0)$ or released $(>0)$ from the deep authigenic (possibly clay) phase $\left(f_{\text {auth }}\right)$ and authigenic Fe oxides $\left(f_{F e O x}\right)$; (D) the calculated Ge isotope composition of the two authigenic phases; (E) the calculated fraction of allogenic Ge supply by lithogenic particles and bSi; (F) the assigned Ge isotope composition of lithogenic and bSi phases, and the calculated composition of total allogenic Ge input $\left(\delta^{74} \mathrm{Ge}\right.$ supply).

$0.3 \mathrm{mmol} \mathrm{m}^{-2} \mathrm{~d}^{-1}$ during 2004-2006 (Hammond et al., unpub. data) and the bSi rain to the seafloor of $1.3 \pm 0.2 \mathrm{mmol} \mathrm{m}^{-2} \mathrm{~d}^{-1}$ during this time, measured using sediment traps (Collins et al., 2011). $\mathrm{Ge} / \mathrm{Si}_{\mathrm{bSi}}$ is taken to be equivalent to deep $\mathrm{Ge} / \mathrm{Si}_{\mathrm{sw}}$ in the California Margin, as confirmed by a bSi-targeting weak alkaline leach of the trap material of Collins et al. (2011) [Supplementary Material of Baronas et al. (2016)].

The detrital Ge flux can be estimated from the external $\mathrm{Fe}$ (oxy)hydroxide input to SPB sediments, which was previously calculated by Leslie et al. (1990) as the flux required to sustain the pyrite burial flux, equal to $26 \mathrm{Fe} \mu \mathrm{mol} \mathrm{m}^{-2} \mathrm{~d}^{-1}$. Making the simplifying assumption that reducible Fe oxides are the dominant lithogenic source of dissolved $\mathrm{Ge}$ in these sediments, the detrital Ge flux can be calculated from the $\mathrm{Ge} / \mathrm{Fe}$ ratio of these oxides. Given that both Ge and Fe are highly immobile and mostly retained in the solid phases during weathering (Gaillardet et al., 2014; Baronas et al., 2018), detrital Fe oxides should have Ge/Fe that is similar to continental crust, i.e., around $27 \mu \mathrm{mol} / \mathrm{mol}$ (Rudnick and Gao, 2014). Using Ge/Fe $=27 \pm 10 \mu \mathrm{mol} / \mathrm{mol}$ yields a lithogenic-derived $\mathrm{Ge}$ contribution to pore waters $\left(\mathrm{F}_{\text {lith }}\right)$ of $0.70 \pm 0.26 \mathrm{nmol} \mathrm{m}^{-2} \mathrm{~d}^{-1}$. The isotopic composition of this detrital flux should be close to the crustal value, given that more than $95 \%$ of river-delivered Ge is retained in the solid phase and that riverine suspended sediment $\delta^{74} \mathrm{Ge}$ composition is for the most part indistinguishable from primary igneous rock values (Baronas et al., 2018).

The allogenic supply of dissolved Ge to the sediments is therefore:

$$
\mathrm{F}_{\text {supply }}=\mathrm{F}_{\mathrm{bSi}}+\mathrm{F}_{\text {lith }}
$$

and its isotopic composition:

$$
\delta^{74} \mathrm{Ge}_{\text {supply }}=\frac{\mathrm{F}_{\mathrm{bSi}} \cdot \delta^{74} \mathrm{Ge}_{\mathrm{bSi}}+\mathrm{F}_{\text {lith }} \cdot \delta^{74} \mathrm{Ge}_{\text {lith }}}{\mathrm{F}_{\text {supply }}}
$$


Finally, the measured incubation flux $\left(\mathrm{F}_{\text {inc }}\right)$ is affected by the sequestration or release of $\mathrm{Ge}$ by authigenic phases, which we here separate into iron oxides (FeOx; note that these are authigenic oxides that precipitate and dissolve within sediments, distinct from the detrital rain-delivered Fe oxides denoted above as lith) and other authigenic phases, such as authigenic clays (auth):

$$
\begin{aligned}
\mathrm{F}_{\text {inc }}= & \mathrm{F}_{\text {supply }}+\mathrm{F}_{\mathrm{FeOx}}+\mathrm{F}_{\text {auth }} \\
\delta^{74} \mathrm{Ge}_{\text {inc }} \cdot \mathrm{F}_{\text {inc }}= & \delta^{74} \mathrm{Ge}_{\text {supply }} \cdot \mathrm{F}_{\text {supply }}+\delta^{74} \mathrm{Ge}_{\mathrm{FeOx}} \cdot \mathrm{F}_{\mathrm{FeOx}} \\
& +\delta^{74} \mathrm{Ge}_{\text {auth }} \cdot \mathrm{F}_{\text {auth }}
\end{aligned}
$$

where positive $\mathrm{F}$ values indicate $\mathrm{Ge}$ release into dissolved phase, and negative $\mathrm{F}$ values indicate $\mathrm{Ge}$ sequestration into solid phase. The isotopic composition of $\mathrm{FeOx}$ is simply

$$
\delta^{74} \mathrm{Ge}_{\mathrm{FeOx}}=\delta^{74} \mathrm{Ge}_{\text {supply }}+\Delta^{74} \mathrm{Ge}_{\mathrm{FeOx}-\text { diss }}
$$

where $\Delta^{74} \mathrm{Ge} e_{\mathrm{FeO} \text {-diss }}$ is assigned the experimentally determined range between -1.6 and $-4.6 \%$ (Pokrovsky et al., 2014). In the case of downcore authigenic phases, no experimental or theoretical $\Delta^{74} \mathrm{Ge}_{\text {auth-diss }}$ values are available. However, the lack of pore water $\delta^{74} \mathrm{Ge}_{\mathrm{pw}}$ gradient observed at SPB (Figure 1) limits $\Delta^{74} \mathrm{Ge}_{\text {auth-diss }}$ to $0 \pm 0.3 \%$. The isotopic composition of this downcore authigenic phase is then

$$
\delta^{74} \mathrm{Ge}_{\text {auth }}=\delta^{74} \mathrm{Ge}_{\mathrm{pw}}+\Delta^{74} \mathrm{Ge}_{\text {auth-diss }}
$$

Using $\delta^{74} \mathrm{Ge}_{\mathrm{pw}}$ instead of $\delta^{74} \mathrm{Ge}_{\text {supply }}$ for the initial value is necessary in this case, to allow for the potential influence of isotopically distinct $\mathrm{Ge}$ released from reductive $\mathrm{FeOx}$ dissolution higher in the sediment column.

Equations (8-11) can be combined to solve for $\mathrm{F}_{\mathrm{FeOx}}$ and $\mathrm{F}_{\text {auth }}$.

The fractions of Ge supplied or consumed by different phases are defined as fractions of the allogenic supply:

$$
\begin{aligned}
\mathrm{f}_{\text {lith }} & =\mathrm{F}_{\text {lith }} / \mathrm{F}_{\text {supply }} \\
\mathrm{f}_{\mathrm{bSi}} & =\mathrm{F}_{\mathrm{bSi}} / \mathrm{F}_{\text {supply }} \\
\mathrm{f}_{\mathrm{FeOx}} & =\mathrm{F}_{\mathrm{FeOx}} / \mathrm{F}_{\text {supply }} \\
\mathrm{f}_{\text {auth }} & =\mathrm{F}_{\text {auth }} / \mathrm{F}_{\text {supply }} \\
\mathrm{f}_{\text {released }} & =\mathrm{F}_{\text {inc }} / \mathrm{F}_{\text {supply }}
\end{aligned}
$$

Given that $n_{\text {inc }}$ for the incubated cores ranged between 1 and $35 \%$ of $\mathrm{n}_{\text {final }}$, and the similar values between $\delta^{74} \mathrm{Ge}_{\text {initial }}$ and $\delta^{74} \mathrm{Ge}_{\text {final }}$, the calculated $\delta^{74} \mathrm{Ge}_{\text {inc }}$ can be sensitive to analytical and experimental uncertainty. We used a Monte Carlo approach to fully assess this uncertainty and to further deconvolve the various factors influencing $\delta^{74} \mathrm{Ge}_{\text {inc }}$. The above set of calculations is performed a large number of times $(n=1,000,000)$, each time randomly selecting from within the uncertainty range of each given parameter (see Supplementary Material). Finally, the following boundary conditions are applied to remove physically impossible results and very long probability distribution tails that can arise from certain combinations of input parameter values:

$$
\begin{aligned}
\mathrm{F}_{\mathrm{bSi}}, \mathrm{F}_{\text {lith }}, \mathrm{F}_{\text {supply }} & >0 \\
\mathrm{~F}_{\text {auth }} & <0 \\
\mathrm{f}_{\text {auth }} & >-10 \\
\mathrm{f}_{\mathrm{FeOx}} & <10
\end{aligned}
$$

The model results for each individual core are given in Supplementary Material.

\subsection{Implications for the Global Ge Isotope Budget}

Across all incubated cores, the probability distribution of $\delta^{74} \mathrm{Ge}_{\text {inc }}$ is centered around $1.6 \%$ (25-75th percentile range $0.8-2.4 \%$; Table 4; Figure 5B), possibly slightly lighter than the allogenic Ge supply $(1.9 \pm 0.6 \%$; a mixture of isotopically light lithogenic- and isotopically heavy biogenic-sourced $\mathrm{Ge}$ ) but essentially indistinguishable within uncertainty. In long-term mass balance terms, the isotopic composition of $\mathrm{Ge}$ released to pore waters (input) is expected to equal the output, i.e., the combined composition of authigenic phases and the benthic flux. Given that there is no detectable Ge isotope fractionation during authigenic $\mathrm{Ge}$ uptake at depth (i.e. $\Delta^{74} \mathrm{Ge}_{\text {auth-diss }} \approx 0 \%$; see discussion above), the allogenic input and the benthic flux should be isotopically indistinguishable. Any natural Fe redoxinduced perturbations, much like the ones observed during our incubation experiments, reflect a non-steady state process and ultimately should have little effect on Ge benthic flux or authigenic composition. The latter should therefore primarily depend on the ratio of Ge supplied from terrigenous vs. biogenic inputs.

Assuming that the observations at San Pedro Basin are applicable to continental margin sediments in general and making a number of additional simplifying assumptions, we can construct a rough Ge budget for the global continental shelf sediments. All the input parameters used in the following calculations and their range of uncertainties are summarized in Supplementary Material. Using a Monte Carlo approach, the calculations were performed 1 million times, sampling randomly from within the uncertainty of all input parameters. All results below are reported as the $25-75 \%$ confidence interval of the 1 million Monte Carlo calculations. The calculations were performed using MATLAB R2018b, and the source code is given in the Supplementary Material.

Here, we use our data from the San Pedro Basin to determine the fraction of lithogenic particulate Ge that gets released into pore waters $\left(\mathrm{f}_{\text {lith-released }}^{\mathrm{Ge}}\right)$ and, in the absence of similar data from other sites, apply this value globally. First, the total lithogenic Ge flux to SPB sediments is calculated as:

$$
\mathrm{F}_{\text {lith-total }}^{\mathrm{SPB}}=\mathrm{J}_{\text {detrital }}^{\mathrm{SPB}} \cdot \frac{[\mathrm{Ge}]_{\mathrm{UCC}}}{\mathrm{M}_{\mathrm{w}}}
$$

where $J_{\text {detrital }}^{\text {SPB }}=350 \pm 30 \mathrm{mg} \mathrm{m}^{-2} \mathrm{~d}^{-1}$ is the detrital flux measured via sediment traps (Collins et al., 2011), $[\mathrm{Ge}]_{\mathrm{UCC}}=1.4 \pm 0.2 \mathrm{ppm}$ is Ge concentration of average upper 
continental crust (Rudnick and Gao, 2014), and $\mathrm{M}_{\mathrm{W}}=72.6$ $\mathrm{g} / \mathrm{mol}$ is the atomic mass of germanium, yielding $\mathrm{F}_{\text {lith-total }}^{\mathrm{SPB}}$ of 6.4-7.1 nmol m $\mathrm{n}^{-2} \mathrm{~d}^{-1}$.

The net supply of dissolved Ge released to pore waters from detrital particles $\left(\mathrm{F}_{\text {lith-diss }}^{\mathrm{SPB}}\right)$ can be estimated from the amount of detrital $\mathrm{Fe}$ input required to sustain long-term pyrite burial in SPB sediments $\left(J_{\mathrm{FeOx}}^{\mathrm{SPB}}\right.$, calculated to be $26 \mu \mathrm{mol} \mathrm{m}^{-2}$ $\mathrm{d}^{-1}$; Leslie et al., 1990):

$$
\mathrm{F}_{\text {lith-diss }}^{\mathrm{SPB}}=\mathrm{J}_{\mathrm{FeOx}}^{\mathrm{SPB}} \cdot \mathrm{Ge} / \mathrm{Fe}_{\mathrm{UCC}}
$$

where $\mathrm{Ge} / \mathrm{Fe}_{\mathrm{UCC}}=25-30 \mu \mathrm{mol} / \mathrm{mol}$ (Rudnick and Gao, 2014). Equation (18) yields $\mathrm{F}_{\text {lith-net }}^{\mathrm{SPB}}=0.66-0.78 \mathrm{nmol} \mathrm{m}^{-2} \mathrm{~d}^{-1}$, which is the value used in the core incubation model described above. We acknowledge the possibility that $\mathrm{Ge}$ and Fe release from detrital particles may not be stoichiometric but we deem it a reasonable assumption at this stage, given the absence of any data regarding this question.

The fraction of lithogenic Ge that dissolves, i.e., is released to the pore waters is thus:

$$
\mathrm{f}_{\text {lith-released }}=\frac{\mathrm{F}_{\text {lith-diss }}^{\mathrm{SPB}}}{\mathrm{F}_{\text {lith-total }}^{\mathrm{SPB}}}
$$

yielding $\mathrm{f}_{\text {lith-released }}=9.9-11.5 \%$. The global biogenic silica flux to shelf sediments was previously estimated as $16-87 \mathrm{Tmol} / \mathrm{y}$, with about $3 \mathrm{Tmol} / \mathrm{y}$ buried and the rest dissolving (Tréguer and De La Rocha, 2013). Using a $\mathrm{Ge} / \mathrm{Si}_{\mathrm{bSi}}$ ratio of $0.5-0.7 \mu \mathrm{mol} / \mathrm{mol}$ (to account for potential inputs of low-Ge/Si bSi from sponges and radiolarians, e.g., Rouxel and Luais, 2017) yields a biogenic Ge flux of 18-39 Mmol/y to the shelf sediments (Equation 20).

$$
\mathrm{F}_{\text {shelf }}^{\mathrm{bSi}}=\mathrm{FSi}_{\text {shelf }}^{\mathrm{bSi}} \cdot \mathrm{Ge} / \mathrm{Si}_{\mathrm{bSi}}
$$

The total detrital Ge supply to the ocean can be estimated from the total riverine sediment flux (19100 Mt/y; Milliman and Farnsworth, 2011) and [Ge] UCC (given that globally $>95 \%$ of riverine $\mathrm{Ge}$ is transported in the solid phase; Gaillardet et al., 2014), yielding roughly $370 \mathrm{Mmol} \mathrm{Ge} / \mathrm{y}$. Assuming all this detrital material settles on continental shelves and using $\mathrm{f}_{\text {lith-released }}^{\mathrm{Ge}}$ calculated above gives $37 \mathrm{Mmol} / \mathrm{y}$ flux of lithogenic Ge that is released to shelf pore waters globally. This value, however, is bound to be strongly over-estimated, since it is much higher than any of the other fluxes in the global marine Ge budget (Baronas et al., 2017). Indeed, most detrital Ge is locked in primary and secondary silicate phases (Mortlock and Froelich, 1987) that are thermodynamically stable in most marine pore waters (e.g., Helgeson et al., 1969). Therefore, most of the pore water $\mathrm{Ge}$ of lithogenic origin is likely derived from the reduction of amorphous secondary Fe (oxy)hydroxides (Poulton and Raiswell, 2002). Baronas et al. (2018) calculated that for various global rivers, the fraction of dissolved Ge released during weathering that remains in solution $\left(\mathrm{f}_{\text {diss }}^{\mathrm{Ge}}\right.$ ) ranges between 1 and $10 \%$ and therefore Ge uptake into terrestrial secondary phases is between 90 and 99\%. Using a global riverine dissolved Ge flux $\left(\mathrm{F}_{\text {diss }}^{\text {riv }}\right.$ ) of $3.2 \pm 1.2 \mathrm{Mmol} / \mathrm{y}$ (Baronas et al., 2017) yields a total secondary detrital Ge flux to continental margin sediments of 38$95 \mathrm{Mmol} / \mathrm{y}$ (Equation 21), 4-10 Mmol/y of which is then released to pore waters (Equation 22).

$$
\begin{aligned}
& \mathrm{F}_{\text {lith-total }}^{\text {shelf }}=\mathrm{F}_{\text {diss }}^{\text {riv }} \cdot\left(\frac{1}{f_{\text {diss }}^{\mathrm{Ge}}}-1\right) \\
& \mathrm{F}_{\text {lith-diss }}^{\text {shelf }}=\mathrm{F}_{\text {lith-total }}^{\text {shelf }} \cdot \mathrm{f}_{\text {lith-released }}^{\mathrm{Ge}}
\end{aligned}
$$

Using the $\mathrm{F}_{\text {lith-diss }}^{\text {shelf }}$ value calculated here and assuming a dissolved Ge sequestration efficiency between 10 and 60\% (Table 4; Baronas et al., 2016) yields a total shelf authigenic Ge burial flux of $7-18 \mathrm{Mmol} / \mathrm{y}$. The uncertainty of this value is now significantly lower compared to the previous 3-27 Mmol/y estimate of Baronas et al. (2016), demonstrating the power of isotopic mass balance constraints in refining global elemental budgets. Importantly, if $10-60 \%$ of lithogenic-derived $\mathrm{Ge}$ is captured in shelf sediments, the remaining $40-90 \%$ escapes back into the water column, contributing 2.5-6.6 Mmol/y Ge to seawater. This flux is significantly higher than the previous Si budget-based estimate of detrital Ge input to the ocean, $1.6 \pm 1.5 \mathrm{Mmol} / \mathrm{y}$ (Baronas et al., 2017).

The isotopic composition of the allogenic supply to global shelf sediment pore waters is then simply a mixture of the biogenic and the detrital inputs:

$$
\delta^{74} \mathrm{Ge}_{\text {shelf-input }}=\frac{\mathrm{F}_{\mathrm{bSi}}^{\text {shelf }} \cdot \delta^{74} \mathrm{Ge}_{\mathrm{bSi}}+\mathrm{F}_{\text {lith-diss }}^{\text {shelf }} \cdot \delta^{74} \mathrm{Ge}_{\text {lith }}}{\mathrm{F}_{\mathrm{bSi}}^{\text {shelf }}+\mathrm{F}_{\text {lith-diss }}^{\text {shelf }}}
$$

Using $\delta^{74} \mathrm{Ge}_{\text {lith }}=0.58 \pm 0.21 \%$ and $\delta^{74} \mathrm{Ge}_{\mathrm{bSi}}$ of $2.5-$ $3.5 \%$ (to account for the potential contribution of isotopically lighter sponges; Guillermic et al., 2017), Equation (23) yields $\delta^{74} \mathrm{Ge}_{\text {shelf-input }}=2.2-2.7 \%$ o. Reassuringly, this value is similar to the pore water compositions reported for the Southern California and Gulf of Mexico margins here (Table 2). In summary, continental margin sediments are expected to exhibit lower pore water $\delta^{74} \mathrm{Ge}$ relative to open ocean sediments, due to an estimated $12-31 \%$ contribution of dissolved Ge from isotopically light lithogenic particles. Importantly, our observations at San Pedro Basin imply that the shelf pore water $\delta^{74} \mathrm{Ge}$ composition is translated to the deep authigenic Ge sink (likely, aluminosilicate clays) without significant fractionation. Therefore, $\delta^{74} \mathrm{Ge}$ of the long-term benthic flux out of shelf sediments should also equal approximately $2.2-2.7 \%$.

Finally, we can use the refined authigenic Ge burial flux value to estimate the equivalent burial flux of Si. Rahman et al. (2017) showed that anywhere from 50 to $75 \%$ of biogenic Si is typically converted to authigenic clays in continental margin settings. Using previously measured bSi burial rates in San Pedro Basin sediments (Hammond et al., 2000; McManus et al., 2003; Baronas et al., 2016) and assuming that authigenic clay Si burial is three times higher, we can estimate authigenic Si burial rates of about $0.16 \mathrm{mmol} \mathrm{m}^{-2} \mathrm{~d}^{-1}$. Combining this value with independent estimates of authigenic Ge burial (Baronas et al., 2016) yields authigenic clay $\mathrm{Ge} / \mathrm{Si}$ values between 2.2 and $7.6 \mu \mathrm{mol} / \mathrm{mol}$. Assuming these $\mathrm{Ge} / \mathrm{Si}$ values are applicable to margin sediments globally, the authigenic Si burial in continental margins should be 
in the range of $1-8 \mathrm{Tmol} / \mathrm{y}$ (best estimate of $3.1 \mathrm{Tmol} / \mathrm{y}$ ), in good agreement with recent ${ }^{32} \mathrm{Si}$-based estimates of $4.5-4.9 \mathrm{Tmol} / \mathrm{y}$ (Rahman et al., 2017), and sufficient to close the global marine Si budget.

\section{CONCLUSIONS}

We have presented $\mathrm{Ge} / \mathrm{Si}, \delta^{74} \mathrm{Ge}$, and supporting chemical data from seawater, pore waters, and core incubations at three continental margin sites in the Southern California Bight and the Gulf of Mexico. During core incubations the flux of dissolved Ge from sediments was highly variable, likely due to variable oxygenation of the cores, perturbing the Fe redox conditions in shallow sediments. The incubation results demonstrate the strong coupling between $\mathrm{Ge}$ and $\mathrm{Fe}$ in reducing continental margin sediments. Below the very shallow Fe redox boundary, pore water $\delta^{74} \mathrm{Ge}$ is a mixture of $\mathrm{Ge}$ released via dissolution of isotopically heavier biogenic silica and isotopically lighter lithogenic particles (possibly reducible Fe oxides). With depth, the precipitation of a $\mathrm{Ge} / \mathrm{Si}$ enriched authigenic phase (possibly aluminosilicate clays) results in up to $90 \%$ depletion of dissolved Ge. Pore water $\delta^{74} \mathrm{Ge}$ signatures remain constant with depth, suggesting negligible fractionation during this process. Therefore, the pore waters, the authigenic clays, and the long-term benthic flux should all have identical $\delta^{74} \mathrm{Ge}$ signatures within uncertainty. Using global estimates of biogenic and lithogenic Ge input to global continental shelf sediments, we calculate an average lithogenic Ge contribution of $12-31 \%$, with the resulting average dissolved $\delta^{74} \mathrm{Ge}$ of $2.2-2.7 \%$ in the continental margin.

\section{DATA AVAILABILITY}

All data discussed in this study is supplied in the main text and Supplementary Tables.

\section{REFERENCES}

Aller, R. C. (2014). "Sedimentary Diagenesis, Depositional Environments, and Benthic Fluxes," in Treatise on Geochemistry, 2nd Edn, eds H. D. Holland and K. K. Turekian (Amsterdam: Elsevier), 293-334.

Baronas, J. J., Hammond, D. E., Berelson, W. M., McManus, J., and Severmann, S. (2016). Germanium-silicon fractionation in a river-influenced continental margin: The Northern Gulf of Mexico. Geochim. Cosmochim. Acta 178, 124142. doi: $10.1016 /$ j.gca.2016.01.028

Baronas, J. J., Hammond, D. E., McManus, J., Wheat, C. G., and Siebert, C. (2017). A global Ge isotope budget. Geochim. Cosmochim. Acta 203, 265-283. doi: 10.1016/j.gca.2017.01.008

Baronas, J. J., Torres, M. A., West, A. J., Rouxel, O., Georg, B., Bouchez, J., et al. (2018). Ge and Si isotope signatures in rivers: a quantitative multi-proxy approach. Earth Planet. Sci. Lett. 503, 194-215. doi: 10.1016/j.epsl.2018.09.022

Belissont, R., Boiron, M.-C., Luais, B., and Cathelineau, M. (2014). LA-ICP-MS analyses of minor and trace elements and bulk Ge isotopes in zoned Gerich sphalerites from the Noailhac Saint-Salvy deposit (France): insights into incorporation mechanisms and ore deposition processes. Geochim. Cosmochim. Acta 126, 518-540. doi: 10.1016/j.gca.2013.10.052

\section{AUTHOR CONTRIBUTIONS}

JB and DH designed the study. JB and DM collected the samples. $\mathrm{JB}$ and $\mathrm{OR}$ performed Ge isotope analyses. JB performed the experiments and modeling and wrote the article, with input from all co-authors.

\section{FUNDING}

Financial support for the SPB cruise was provided by US National Science Foundation (NSF) grant OCE-1260692 to DH. SMB cruise was supported by US NSF grants OCE0962209 to Sergio Sañudo-Wilhelmy, OCE-0934073 to Douglas Capone, and PLR-1029878 to William Berelson. Additional support was provided by US NSF grant OCE1061700 to DH. JB was also supported by a CUAHSI Pathfinder graduate student fellowship, an InterRidge research fellowship, and a John Montagne Award from GSA Quaternary Geology and Geomorphology Division. Support for OR was provided by the Institut Carnot Ifremer EDROME and the LabexMer ANR-10-LABX-19-01.

\section{ACKNOWLEDGMENTS}

We thank the crew of R/V Yellowfin, Nick Rollins, Elias Karkabi, Brian Seegers, and Will Berelson for their assistance with sample collection and processing. We also thank Emmanuel Ponzevera for assistance with $\mathrm{Ge}$ isotope measurements at Ifremer. Two reviewers are thanked for their constructive comments that helped improve the manuscript.

\section{SUPPLEMENTARY MATERIAL}

The Supplementary Material for this article can be found online at: https://www.frontiersin.org/articles/10.3389/feart. 2019.00162/full\#supplementary-material

Berelson, W. M. (1991). The flushing of two deep-sea basins, southern California borderland. Limnol. Oceanogr. 36, 1150-1166.

Berelson, W. M., Hammond, D. E., and Johnson, K. (1987). Benthic fluxes and the cycling of biogenic silica and carbon in two southern California borderland basins. Geochim. Cosmochim. Acta 51, 1345-1363. doi: 10.1016/0016-7037(87)90320-6

Bower, C., and Holm-Hansen, T. (1980). A salicylate-hypochlorite method for determining ammonia in seawater. Can. J. Fish. Aquat. Sci. 37, 794-798.

Burton, J., Culkin, F., and Riley, J. (1959). The abundances of gallium and germanium in terrestrial materials. Geochim. Cosmochim. Acta 16, 151-180.

Cheng, T., Hammond, D. E., Berelson, W. M., Hering, J. G., and Dixit, S. (2009). Dissolution kinetics of biogenic silica collected from the water column and sediments of three Southern California borderland basins. Mar. Chem. 113, 41-49. doi: 10.1016/j.marchem.2008.12.001

Collins, L. E., Berelson, W. M., Hammond, D. E., Knapp, A., Schwartz, R., and Capone, D. (2011). Particle fluxes in San Pedro Basin, California: a four-year record of sedimentation and physical forcing. Deep Sea Res. I 58, 898-914. doi: 10.1016/j.dsr.2011.06.008 
De La Rocha, C. L., Brzezinski, M. A., and DeNiro, M. J. (2000). A first look at the distribution of the stable isotopes of silicon in natural waters. Geochim. Cosmochim. Acta 64, 2467-2477. doi: 10.1016/S0016-7037(00)00373-2

Ehlert, C., Doering, K., Wallmann, K., Scholz, F., Sommer, S., Grasse, P., et al. (2016). Stable silicon isotope signatures of marine pore waters-biogenic opal dissolution versus authigenic clay mineral formation. Geochim. Cosmochim. Acta 191, 102-117. doi: 10.1016/j.gca.2016.07.022

Elderfield, H., and Schultz, A. (1996). Mid-ocean ridge hydrothermal fluxes and the chemical composition of the ocean. Annu. Rev. Earth Planet. Sci. 24, 191-224.

Ellwood, M. J., Kelly, M., Maher, W. A., and De Deckker, P. (2006). Germanium incorporation into sponge spicules: development of a proxy for reconstructing inorganic germanium and silicon concentrations in seawater. Earth Planet. Sci. Lett. 243, 749-759. doi: 10.1016/j.epsl.2006.01.016

Ellwood, M. J., and Maher, W. A. (2003). Germanium cycling in the waters across a frontal zone: the Chatham Rise, New Zealand. Mar. Chem. 80, 145-159. doi: 10.1016/S0304-4203(02)00115-9

Ellwood, M. J., Wille, M., and Maher, W. (2010). Glacial silicic acid concentrations in the Southern Ocean. Science 330, 1088-1091. doi: 10.1126/science.1194614

Elrod, V. A. (2004). The flux of iron from continental shelf sediments: a missing source for global budgets. Geophys. Res. Lett. 31:L12307. doi: 10.1029/2004GL020216

Escoube, R., Rouxel, O. J., Edwards, K., Glazer, B., and Donard, O. F. X. (2015). Coupled $\mathrm{Ge} / \mathrm{Si}$ and $\mathrm{Ge}$ isotope ratios as geochemical tracers of seafloor hydrothermal systems: Case studies at Loihi Seamount and East Pacific Rise $9^{\circ} 50^{\prime}$ N. Geochim. Cosmochim. Acta 167, 93-112. doi: 10.1016/j.gca. 2015.06.025

Escoube, R., Rouxel, O. J., Luais, B., Ponzevera, E., and Donard, O. F. (2012). An intercomparison study of the Germanium isotope composition of geological reference materials. Geostand. Geoanal. Res. 36, 149-159. doi: 10.1111/j.1751-908X.2011.00135.x

Froelich, P., and Andreae, M. (1981). The marine geochemistry of germanium: Ekasilicon. Science 213, 205-207.

Froelich, P., Blanc, V., Mortlock, R., Chillrud, S., Dunstan, W., Udomkit, A., et al. (1992). River fluxes of dissolved silica to the ocean were higher during glacials: $\mathrm{Ge} / \mathrm{Si}$ in diatoms, rivers, and oceans. Paleoceanography 7, 739-767.

Froelich, P., Hambrick, G., Andreae, M., Mortlock, R., and Edmond, J. (1985). The geochemistry of inorganic germanium in natural waters. J. Geophys. Res. 90, 1133-1141.

Gaillardet, J., Viers, J., and Dupré, B. (2014). “Chapter 7.7: Trace Elements in River Waters," in Treatise on Geochemistry, 2nd Edn, eds H. D. Holland and K. K. Turekian (Amsterdam: Elsevier), 195-235.

Gorsline, D. (1992). The geological setting of Santa Monica and San Pedro Basins, California Continental Borderland. Prog. Oceanogr. 30, 1-36.

Guillermic, M., Lalonde, S. V., Hendry, K. R., and Rouxel, O. J. (2017). The isotope composition of inorganic germanium in seawater and deep sea sponges. Geochim. Cosmochim. Acta 212, 99-118. doi: 10.1016/j.gca.2017.06.011

Hammond, D. E., Cummins, K. M., McManus, J., Berelson, W. M., Smith, G., and Spagnoli, F. (2004a). Methods for measuring benthic nutrient flux on the California Margin: comparing shipboard core incubations to in situ lander results. Limnol. Oceanogr. Methods 2, 146-159. doi: 10.4319/lom.2004.2.146

Hammond, D. E., McManus, J., and Berelson, W. M. (2004b). Oceanic germanium/silicon ratios: evaluation of the potential overprint of temperature on weathering signals. Paleoceanography 19:PA2016. doi: 10.1029/2003PA000940

Hammond, D. E., McManus, J., Berelson, W. M., Meredith, C., Klinkhammer, P., and Coale, K. (2000). Diagenetic fractionation of $\mathrm{Ge}$ and $\mathrm{Si}$ in reducing sediments: the missing $\mathrm{Ge}$ sink and a possible mechanism to cause glacial/interglacial variations in oceanic Ge/Si. Geochim. Cosmochim. Acta 64, 2453-2465. doi: 10.1016/S0016-7037(00)00362-8

Helgeson, H. C., Garrels, R. M., and MacKenzie, F. T. (1969). Evaluation of irreversible reactions in geochemical processes involving minerals and aqueous solutions-II. Applications. Geochim. Cosmochim. Acta 33, 455-481. doi: 10.1016/0016-7037(69)90127-6

Hickey, B. M. (1992). Circulation over the Santa Monica-San Pedro Basin and Shelf. Prog. Oceanogr. 30, 37-115. doi: 10.1016/0079-6611(92)90009-O

John, S. G., Mendez, J., Moffett, J., and Adkins, J. (2012). The flux of iron and iron isotopes from San Pedro Basin sediments. Geochim. Cosmochim. Acta 93, 14-29. doi: 10.1016/j.gca.2012.06.003
King, S., Froelich, P., and Jahnke, R. (2000). Early diagenesis of germanium in sediments of the Antarctic South Atlantic: in search of the missing Ge sink. Geochim. Cosmochim. Acta 64, 1375-1390. doi: 10.1016/S0016-7037(99)00406-8

Kurtz, A., Derry, L., and Chadwick, O. (2002). Germanium-silicon fractionation in the weathering environment. Geochim. Cosmochim. Acta 66, 1525-1537. doi: 10.1016/S0016-7037(01)00869-9

Leslie, B. W., Hammond, D. E., Berelson, W. M., and Lund, S. P. (1990). Diagenesis in anoxic sediments from the California continental borderland and its influence on iron, sulfur, and magnetite behavior. J. Geophys. Res. 95:4453. doi: 10.1029/JB095iB04p04453

Lewis, B., Andreae, M., and Froelich, P. (1989). Sources and sinks of methylgermanium in natural waters. Mar. Chem. 27, 179-200.

Lewis, B., Andreae, M., Froelich, P. N., and Mortlocka, R. A. (1988). A review of the biogeochemistry of germanium in natural waters. Sci. Total Environ. 73, 107-120.

Lewis, B., Froelich, P., and Andreae, M. (1985). Methylgermanium in natural waters. Nature 313, 303-305.

Luais, B. (2007). Isotopic fractionation of germanium in iron meteorites: significance for nebular condensation, core formation and impact processes. Earth Planet. Sci. Lett. 262, 21-36. doi: 10.1016/j.epsl.2007.06.031

Luais, B. (2012). Germanium chemistry and MC-ICPMS isotopic measurements of $\mathrm{Fe}-\mathrm{Ni}, \mathrm{Zn}$ alloys and silicate matrices: insights into deep Earth processes. Chem. Geol. 334, 295-311. doi: 10.1016/j.chemgeo.2012.10.017

Mackenzie, F. T., and Garrels, R. M. (1966). Chemical mass balance between rivers and oceans. Am. J. Sci. 264, 507-525. doi: 10.2475/ajs.264.7.507

Mantoura, S. C. (2006). Development and Application of Opal Based Paleoceanographic Proxies ( $\mathrm{PhD}$ thesis). University of Cambridge.

McManus, J., Berelson, W. M., Coale, K. H., Johnson, K. S., and Kilgore, T. E. (1997). Phosphorus regeneration in continental margin sediments. Geochim. Cosmochim. Acta 61, 2891-2907. doi: 10.1016/S0016-7037(97)00138-5

McManus, J., Hammond, D. E., Berelson, W. M., Kilgore, T. E., Demaster, D. J., Ragueneau, O. G., et al. (1995). Early diagenesis of biogenic opal: dissolution rates, kinetics, and paleoceanographic implications. Deep Sea Res. II 42, 871903.

McManus, J., Hammond, D. E., Cummins, K., Klinkhammer, G. P., and Berelson, W. M. (2003). Diagenetic Ge-Si fractionation in continental margin environments: further evidence for a nonopal Ge sink. Geochim. Cosmochim. Acta 67, 4545-4557. doi: 10.1016/S0016-7037(03)00385-5

Meng, Y. M., Qi, H. W., and Hu, R. Z. (2015). Determination of germanium isotopic compositions of sulfides by hydride generation MC-ICP-MS and its application to the $\mathrm{Pb}-\mathrm{Zn}$ deposits in SW China. Ore Geol. Rev. 65, 1095-1109. doi: 10.1016/j.oregeorev.2014.04.008

Michalopoulos, P., and Aller, R. C. (1995). Rapid clay mineral formation in Amazon delta sediments: reverse weathering and oceanic elemental cycles. Science 270, 614-617.

Michalopoulos, P., and Aller, R. C. (2004). Early diagenesis of biogenic silica in the Amazon delta: alteration, authigenic clay formation, and storage. Geochim. Cosmochim. Acta 68, 1061-1085. doi: 10.1016/j.gca.2003.07.018

Milliman, J. D., and Farnsworth, K. L. (eds.). (2011). "Oceania," in River Discharge to the Coastal Ocean (Cambridge: Cambridge University Press), 13-69.

Monteverde, D. R., Sylvan, J. B., Suffridge, C., Baronas, J. J., Fichot, E., Fuhrman, J., et al. (2018). Distribution of extracellular flavins in a coastal marine basin and their relationship to redox gradients and microbial community members. Environ. Sci. Technol. 52, 12265-12274. doi: 10.1021/acs.est.8b02822

Mortlock, R., Charles, C., Froelich, P., Zibello, M., Saltzman, J., Hays, J., et al. (1991). Evidence for lower productivity in the Antarctic Ocean during the last glaciation. Nature 351, 220-223.

Mortlock, R., and Froelich, P. (1987). Continental weathering of germanium: Ge/Si in the global river discharge. Geochim. Cosmochim. Acta 51, 2075-2082.

Mortlock, R., and Froelich, P. (1996). Determination of germanium by isotope dilution-hydride generation inductively coupled plasma mass spectrometry. Anal. Chim. Acta 332, 277-284.

Mullin, J., and Riley, J. (1955). The colorimetric determination of silicate with special reference to sea and natural waters. Anal. Chim. Acta 12, 162-175.

Murnane, R., and Stallard, R. (1990). Germanium and silicon in rivers of the Orinoco drainage basin. Nature 344, 749-752. 
Murnane, R. J., Leslie, B., Hammond, D. E., and Stallard, R. F. (1989). Germanium geochemistry in the Southern California Borderlands. Geochim. Cosmochim. Acta 53, 2873-2882.

Pokrovsky, O., Pokrovski, G., Schott, J., and Galy, A. (2006). Experimental study of germanium adsorption on goethite and germanium coprecipitation with iron hydroxide: X-ray absorption fine structure and macroscopic characterization. Geochim. Cosmochim. Acta 70, 3325-3341. doi: 10.1016/j.gca.2006. 04.012

Pokrovsky, O. S., Galy, A., Schott, J., Pokrovski, G. S., and Mantoura, S. (2014). Germanium isotope fractionation during Ge adsorption on goethite and its coprecipitation with Fe oxy(hydr)oxides. Geochim. Cosmochim. Acta 131, 138149. doi: 10.1016/j.gca.2014.01.023

Poulton, S. W., and Raiswell, R. (2002). The low-temperature geochemical cycle of iron: from continental fluxes to marine sediment deposition. Am. J. Sci. 302, 774-805. doi: 10.2475/ajs.302.9.774

Presti, M., and Michalopoulos, P. (2008). Estimating the contribution of the authigenic mineral component to the long-term reactive silica accumulation on the western shelf of the Mississippi River Delta. Continent. Shelf Res. 28, 823-838. doi: 10.1016/j.csr.2007.12.015

Qi, H. W., Hu, R. Z., Jiang, K., Zhou, T., Liu, Y. F., and Xiong, Y. W. (2019). Germanium isotopes and Ge/Si fractionation under extreme tropical weathering of basalts from the Hainan Island, South China. Geochim. Cosmochim. Acta 253, 249-266. doi: 10.1016/j.gca.2019.03.022

Rahman, S., Aller, R. C., and Cochran, J. K. (2016). Cosmogenic 32 Si as a tracer of biogenic silica burial and diagenesis: Major deltaic sinks in the silica cycle. Geophys. Res. Lett. 43, 7124-7132. doi: 10.1002/2016GL069929

Rahman, S., Aller, R. C., and Cochran, J. K. (2017). The missing silica sink: revisiting the marine sedimentary Si cycle using cosmogenic 32 Si. Glob. Biogeochem. Cycles 31, 1559-1578. doi: 10.1002/2017GB005746

Rouxel, O., Galy, A., and Elderfield, H. (2006). Germanium isotopic variations in igneous rocks and marine sediments. Geochim. Cosmochim. Acta 70, 33873400. doi: 10.1016/j.gca.2006.04.025

Rouxel, O. J., and Luais, B. (2017). Germanium isotope geochemistry. Rev. Mineral. Geochem. 82, 601-656. doi: 10.2138/rmg.2017.82.14
Rudnick, R., and Gao, S. (2014). "Composition of the continental crust," in Treatise on Geochemistry, 2 Edn, eds H. D. Holland and K. K. Turekian (Amsterdam: Elsevier), 1-51.

Severmann, S., McManus, J., Berelson, W. M., and Hammond, D. E. (2010). The continental shelf benthic iron flux and its isotope composition. Geochim. Cosmochim. Acta 74, 3984-4004. doi: 10.1016/j.gca.2010.04.022

Siebert, C., Nägler, T., and Kramers, J. (2001). Determination of molybdenum isotope fractionation by double-spike multicollector inductively coupled plasma mass spectrometry. Geochem. Geophys. Geosyst. 2, 1-16. doi: 10.1029/2000GC000124

Sutton, J., Ellwood, M. J., Maher, W. A., and Croot, P. L. (2010). Oceanic distribution of inorganic germanium relative to silicon: Germanium discrimination by diatoms. Glob. Biogeochem. Cycles 24:GB2017. doi: 10.1029/2009GB003689

Tréguer, P. J., and De La Rocha, C. L. (2013). The world ocean silica cycle. Annu. Rev. Mar. Sci. 5, 477-501. doi: 10.1146/annurev-marine-121211-172346

Van Cappellen, P. (2003). Biomineralization and global biogeochemical cycles. Rev. Mineral. Geochem. 54, 357-381. doi: 10.2113/0540357

Ziegler, K., Chadwick, O. A., Brzezinski, M. A., and Kelly, E. F. (2005). Natural variations of $\mathrm{d} 30 \mathrm{Si}$ ratios during progressive basalt weathering, Hawaiian Islands. Geochim. Cosmochim. Acta 69, 4597-4610. doi: 10.1016/j.gca.2005.05.008

Conflict of Interest Statement: The authors declare that the research was conducted in the absence of any commercial or financial relationships that could be construed as a potential conflict of interest.

Copyright (c) 2019 Baronas, Hammond, Rouxel and Monteverde. This is an openaccess article distributed under the terms of the Creative Commons Attribution License (CC BY). The use, distribution or reproduction in other forums is permitted, provided the original author(s) and the copyright owner(s) are credited and that the original publication in this journal is cited, in accordance with accepted academic practice. No use, distribution or reproduction is permitted which does not comply with these terms. 